\title{
Roman Soldiers and Imperial Properties in the Galatian-Phrygian Borderland: A New Inscription from the Eskişehir Museum
}

\author{
Hüseyin UZUNOĞLU *
}

The expansion of the Roman Empire to the Euphrates border and the inevitably increasing military movements across Asia Minor as a transition point for the Roman army gave rise the frequent conflicts from $2^{\text {nd }}$ cent. A.D. to Late Antiquity between the rural communities and the soldiers, who ravaged their properties and the imperial estates and harassed them in various ways. The petitions of the peasants and the imperial responses compiled by Tor Hauken testify that particularly the regions of Lydia and Phrygia were severely affected from this phenomenon ${ }^{1}$. The

* Asst. Prof. Dr. Hüseyin Uzunoğlu, Akdeniz University, Faculty of Letters, Department of Ancient Languages and Cultures, Antalya (huseyinuzunoglu@akdeniz.edu.tr; https://orcid.org/0000-0001-7707-4647).

Many people and institutions played a part in the completion of this paper; Therefore, I have a long list of people to thank. First and foremost, I would like to thank my dear teacher Prof. Dr. N. Eda Akyürek Şahin (Akdeniz University) for entrusting me with the publication of this important document. She has been working in the Eskişehir Archaeological Museum since 2004 and managed to copy plenty of new inscriptions which have already been published or which are still in progress for publication. Now, with the collaboration of Thomas Corsten (Vienna) and Christian Marek (Zurich), we have undertaken the job to bring to a completion Peter Frei's corpus of Dorylaion which was unfortunately left unfinished upon his death. So, many of the newly recorded epigraphic material will be incorporated in the corpus which is planned to be published in the TAM series in three years time. We (N. Eda Akyürek Şahin and I) sincerely thank Mrs Emriye Yurt, the current director of the Eskişehir Archaeological Museum and the late Dursun Çağlar, the former director of the museum, for giving us permission to work on the epigraphic collection of the museum as well as the archaeologists Zeki Bürkük and Gülsüm Baykal Okta for their hospitality. I also thank Prof. Dr. Fatih Onur (Akdeniz University) for his help in recording the inscription.

This paper was presented at the 'Oxford Epigraphy Workshop, in January 2019, at the Ausonius Institute in Bordeaux in May 2019 and lastly at the 'Third North American Congress of Greek and Latin Epigraphy (NACGLE)' held in January 2020 in Washington D.C. My sincere thanks go to Peter Thonemann and Charles Crowther (both in Oxford) and the organizing committee of NACGLE 2020 for their invitations to these fruitful organizations and I also thank the participants in these events for the discussions and valuable suggestions that are incorporated in this contribution in one way or another. I am particularly indebted to Dr. Alberto Dalla Rosa (Ausonius Institute, Bordeaux) as well as Prof. Tor Hauken (Bergen) for reading the manuscript thoroughly and saved me from errors. I wish to thank two anonymous reviewers for their helpful comments and constructive remarks. All remaining errors, needless to say, are entirely my own. This paper also forms a part of my post-doctoral project entitled "The Roman military presence in Phrygia and Galatia and its impact on urban and rural communities”, which was generously supported by the Research Center for Anatolian Civilizations at Koç University (ANAMED) between September 2019 and February 2020 as a part of a residential fellowship.

${ }^{1}$ The only exceptions being outside of Lydia and Phrygia are known from Euhippe in Caria (Hauken 1998, 215-216) and from the Mycale Peninsula (Hauken - Malay 2009). See now a new inscription from Choma in Northern Lycia in Reger 2020 which contains a rescript of Septimius Severus responding to the complaints of the Lycian League about the soldiers applying torture in the Lycian cities. After P. Herrmann's 
peasants or tenant farmers suffered substantially from the incursions and unjustified requisitions of the ill disciplined and greedy soldiers attempted to tackle the issue desperately through petitioning either directly to the emperor or to the provincial governor, apparently without a permanent solution as can be inferred from the complaints reiterated over a very long period of time $^{2}$. Based on the fact that these complaints are overwhelmingly attested from the province of Asia and no document is known from Bithynia, Cilicia and the central Anatolian provinces, Stephen Mitchell argued that "some protection was provided on these important transit routes by centurions and other officers to keep the peace between the armies and the civilian population and all these roads were major military highways where hospitality, provisions, transport, and other contributions could be claimed by right"3. The new inscription recorded at the Eskişehir Archaeological Museum and edited below in this paper, given its findspot, constitutes the first document in this sense, clearly illustrating that even on the major highways full control and peace could not be maintained.

According to the museum authorities, this monument was transported to the museum from the county of Mihalıççı, ca. $100 \mathrm{~km}$ north-east of Eskişehir, which lay on the Galatian-Phrygian

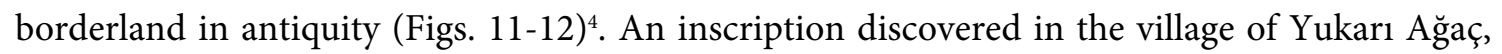
lying ca. 10-12 km south of Mihalıçcık demonstrate that these lands were imperial properties, called Choria Considiana ${ }^{5}$ and its name indicates that its original owner had been a Considius, and the existence of freedmen in the area with the praenomen and nomen P. Aelius indicates that it was converted to an imperial estate in the reign of Hadrian ${ }^{6}$. Another inscription from the same village relates that a priest, a priestess and their children made a vow at an altar to Zeus of the inhabitants of seven villages, from which Mitchell justifiably contends that Choria Considiana originally composed a group of seven villages ${ }^{7}$. The expressions in the first two lines as well as the

compilation of the documents in 1990 followed by T. Hauken in 1998, only a few new documents (from Asia Minor) relating to this topic have appeared, see Hauken et al. 2003, the text republished and improved by Lampe - Tabbernee 2004, 169-178 = Tabbernee - Lampe 2008, 49-84 (Tymion); Hauken - Malay 2009 $=\mathrm{AE} 2009,1428=$ SEG 59, 1365 (the Mycale Peninsula); cf. also the new edition of RECAM III 112 by Souris - Haensch 2009 (Karamanlı/near Kibyra). The topic has become the subject of extensive discussions with a particular emphasis on the $3^{\text {rd }}$ century crisis in the Roman Empire, see in general Scheidel 1991; Speidel 2015. For a critical assessment of the documents with a useful appendix see Haensch 2019, who does not accept the argument of Speidel (2009) who does not read military anarchy in the petition dossier and evaluates them in the context of the increasing passage of Roman military units to the Parthian frontier. Cf. also SEG 59, 1943.

${ }^{2}$ Cf. Rance 2019.

${ }^{3}$ Mitchell 1993, 232.

${ }^{4}$ Unfortunately, because no further detail for the provenance is provided by the museum directorate, we cannot pinpoint the precise location where the inscription originated.

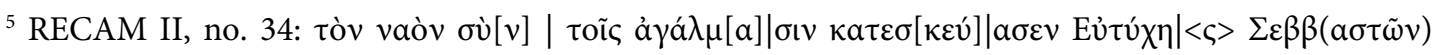

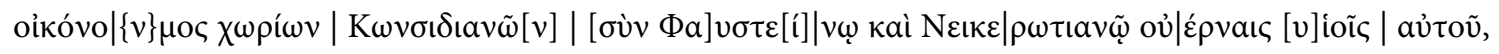

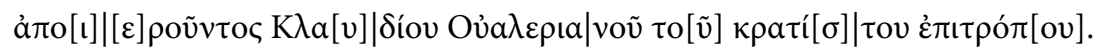

${ }^{6}$ Mitchell 1993, 153 and 156. A. Dalla Rosa $(2014,338)$ leaves open the possibility that the lands might well belong to two Considii who were condemned for treason in the time of Tiberius, but also shares the view of Mitchell saying that there is no concrete evidence linking this family to Galatia or Asia Minor.

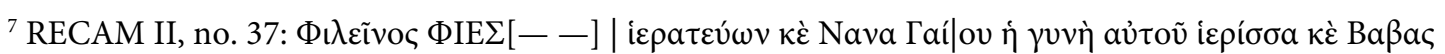




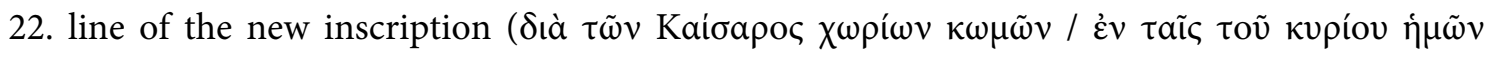

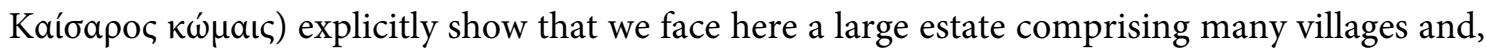
given the proximity of the two find-spots, it can with near absolute certainty be said that the imperial estate of this new inscription is identical with that named Choria Considiana ${ }^{8}$.

Marble stele (Figs. 7-10). Broken at the top and bottom. The stone is almost intact on the left and on the right. Some lines (16 to 20), particularly in the middle section of the stone have been exposed to extreme abrasion and are hardly legible. ${ }^{9}$ Currently kept in the garden of the museum. No inventory number has yet been given.

Measurements: H: $96 \mathrm{~cm}$; W: $60 \mathrm{~cm}$; D: 12-15 cm; Lh: 1,8-2,5 cm.

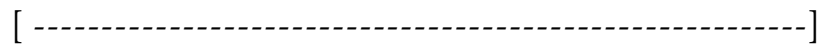

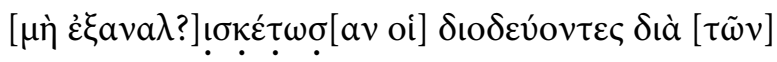

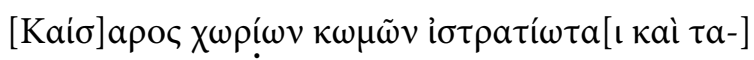

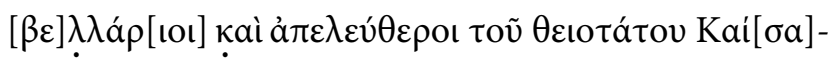

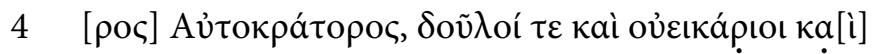

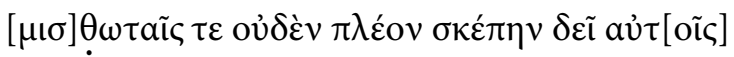

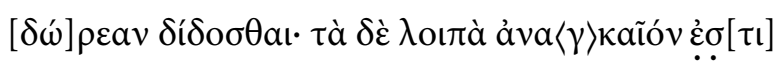

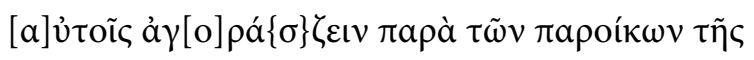

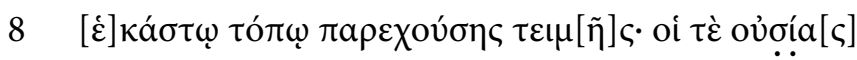

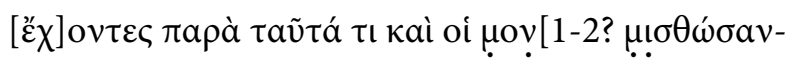

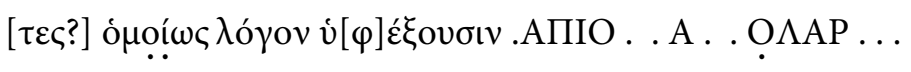

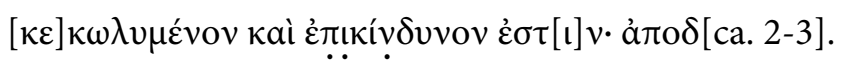

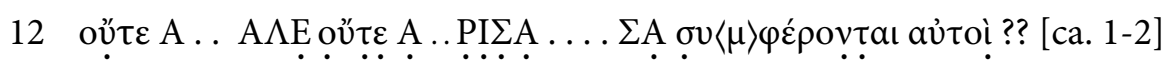

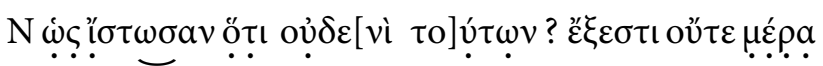

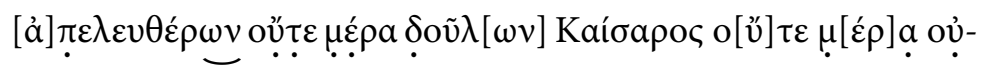

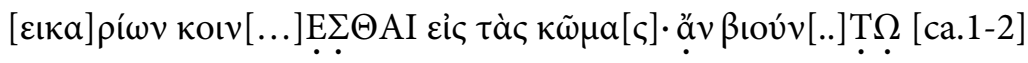

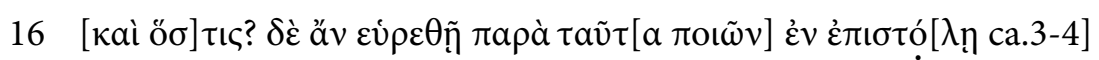

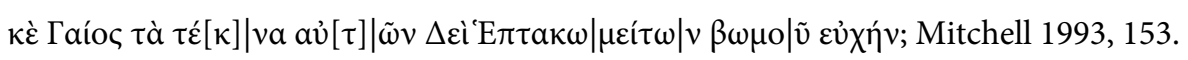

${ }^{8}$ For Choria Considiana, see the studies of Hale Güney (Aarhus) who has been surveying the area since 2015 and published many new inscriptions enhancing our knowledge: Güney 2016; Güney 2018; Güney 2019; Güney, forthcoming. There is indeed another estate belonging to family of Plancii in the ancient settlement of Phyle (Beyköy) in the environs of Mihalıç̧̧k, see Mitchell 1974; TIB 4, 215 s.v. Phyle; Güney 2019, 157.

${ }^{9}$ I am particularly grateful to my friend and colleague Aykan Akçay (Akdeniz University) who worked with me in the museum in early November 2019 to apply RTI to the monument, and through his ingenious use of the RTI software many otherwise invisible details have been captured. For the benefits of RTI in epigraphy see Akçay 2016. 


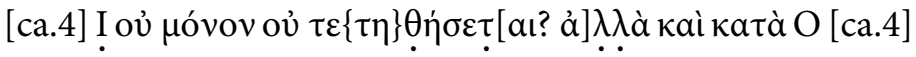

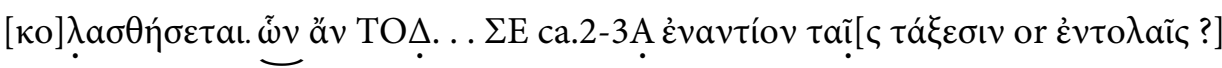

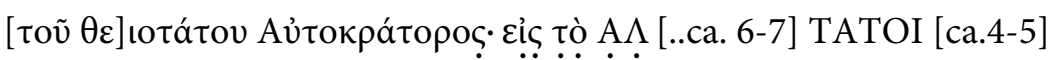

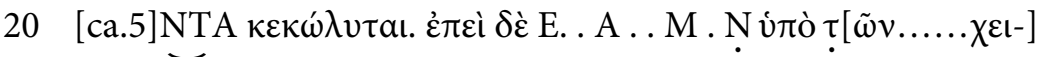

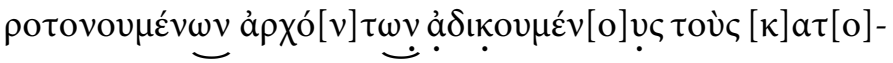

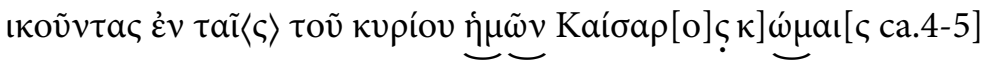

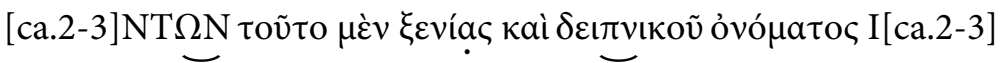

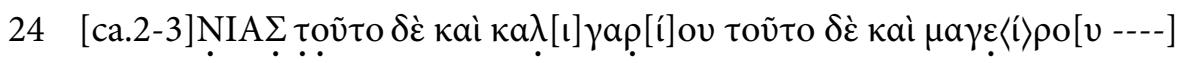

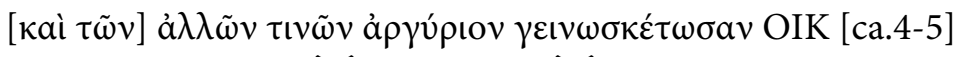

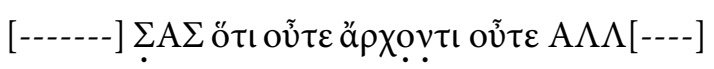

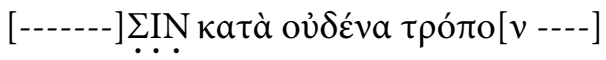

$[---\varepsilon \dot{v}$ ?] $\tau \alpha \xi \hat{́} \alpha v \mathrm{~K}[----]$

$[-$

Translation: "---- The soldiers who march through the estates and villages of the emperor and the tabularii, and the freedmen of the most divine emperor Caesar, as well as the slaves, the vicarii shall not use up---and it is not necessary for the misthotai to provide for free to these persons anything else than shelter. It is compulsory for them to buy the rest from the inhabitants in each place at the market price. Both the property owners [who act] against these and those who lease will render account similarly..... it is hindered and insecure ----- Since they had known that no one from among these people are allowed to ----- (distribute??) the shares of the freedmen, the imperial slaves and the vicarii to the villages. If anyone is found [acting] against the things [written] in the letter?, he ----will not only pay [the penalty?] but also will be punished. ------ something contrary to the [orders?] of the most divine emperor ---- Since ------ the harassed inhabitants in the villages of our lord Caesar by the elected officials ------They shall recognize that the money of the bootmaker? and the butcher? and the others is ---- neither to the official nor ---- in any manner ---".

The upper and lower sections are broken off and many details are sadly lost. Hence, the nature and characteristics of the inscription cannot be judged straightforwardly. The reference to an epistole in 1.16 may possibly indicate that an imperial rescript, not a subscriptio ${ }^{10}$ was carved at the beginning of the stone. The surviving part of the inscription containing many detailed instructions are in all probability an edict of the imperial legate of Galatia ${ }^{11}$, clearly not of the

${ }^{10}$ For the detailed analysis of the legislative procedures concerning the petitions, see Hauken 1998, 296317, particularly p. 299 for the distinction between a subscriptio and a rescript. Cf. also Reger 2020, 261: "Rescripts in the form of a letter are typically addressed to cities, corporate groups with the same status as or similar to a city, imperial officials, or individuals of high status. They represent a higher level of engagement and more respectful response than the subscriptio, in which the emperor (or rather a member of his staff, the a libellis simply writes his reply at the bottom of the petition".

${ }^{11}$ Iuliopolis was located at the border of Bithynia et Pontus and Galatia, but as it is seen from the corre- 
emperor ${ }^{12}$. We are, on the other hand, not sure if a petition of the villagers stood in the lost parts of the inscription explaining the reasons for their complaints in a rhetorical manner as is usual in many examples, but it is highly possible.

Date: There is unfortunately no hint as to the date of the inscription. The name of the emperor is

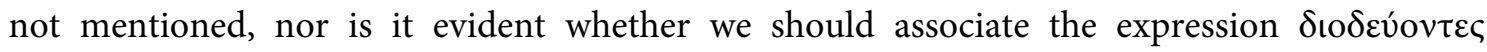
$\sigma \tau \rho \alpha \tau i \omega \tau a \iota$ recorded in the first lines with a specific military campaign. It is highly probable that we face here a general expression, since the area is in close proximity to the main military routes. If we take a look at the book of Tor Hauken's 'Petition and Response' containing many petitions of the villages and estates which complained that they suffered from extensive damage inflicted by the troops looting their farms, we see that they are mostly squeezed into a specific time span, ranging from the end of the $2^{\text {nd }}$ century to the first half of the $3^{\text {rd }}$ century A.D ${ }^{13}$. Given the lettering style, one can also propose a more or less similar date for this new inscription. It is possible to go further and propose a Severan date (as terminus post-quem) because of the "theios" epithet. Although the earliest instance of "theiotatos" in connection with an emperor goes back to 9 B.C. ${ }^{14}$ and there are indeed some documents from the $2^{\text {nd }}$ century in which this epithet is employed ${ }^{15}$, Rougé points out that it becomes much more prevalent with the dynasty of the Severans ${ }^{16}$.

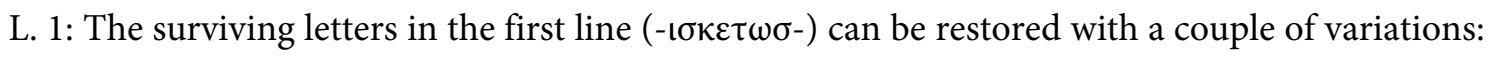

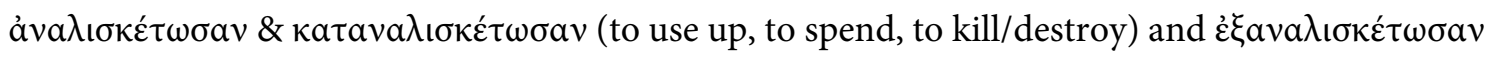
(to lay waste; to destroy utterly). The first two options do not have any parallels in the petition dossier as far as I know (but they are also possible here since there is enough space on the stone),

spondence between Trajan and Pliny the Younger (cf. below fn. 22), it was apparently included in the province of Bithynia et Pontus in the Imperial Period. But, since the findspot of the inscription, the area of Mihalıç̧̧ı, is separated from Bithynia by the Sangarios River, it is quite likely that Choria Considiana was administratively ascribed to the Galatian province, even though Iuliopolis remained in the province of Bithynia-Pontus at least until Diocletian, see Güney 2019, 157. Nevertheless, due to the lack of sufficient evidence, I prefer to avoid making any certain judgment on the territorial borders in this particular area.

${ }^{12}$ It is definitely not the emperor because of the referral to him in lines 3-4 and 20. Given the content of the instructions and the regulations, it is almost without doubt that the author of this document was the imperial legate of Galatia. The other alternative (with a very slight possibility) would be the procurator of the province, but his authority to interfere with the passing of the military personnel or imperial staff through a province does not seem to be sufficient.

${ }^{13}$ However, it is known that the abuses due to wandering soldiers are attested as early as the beginning of the first century AD., see for example OGIS 665 (Girgeh, Egypt); ILS 214; I. Sagalassos I, 3.

${ }^{14}$ See I. Priene, 14, 1.4 and 22 (for the best-preserved version). There are several copies of this decree issued by the proconsul Paulus Fabius Maximus across the province of Asia, see for example the most recently published one in Metropolis: SEG 56, 1233. For the most comphrensive discussion of this text (including all the copies until then), s. Laffi 1967, 5-98.

${ }^{15}$ OGIS, 529; SEG 64, 640; Tanriver 2013, 46-48, no. 41 = SEG 63, 1091 = AE 2013, 1517 (for Hadrian); IGRR I, 608; OGIS 493 and 504 (Antoninus Pius); SIG $^{3} 870$ (Marcus Aurelius and Lucius Verus); IGBulg III,2, 878 (Marcus alone); I.Ephesos 1539 = SEG 50, 1132 (sometime between 150-200 A.D.). Cf. also Hauken 1998, 47-48.

${ }^{16}$ Rougé 1969, 86-88. Moreover, the absence of Caesariani in the inscription may also support this dating since they are mostly attested from mid-3rd century onwards. On this see Haensch 2006, 153-164, p. 162 in particular. 
but we have one example for $\dot{\varepsilon} \xi \alpha v a \lambda i \sigma \kappa \omega$ (albeit similarly restored) from the village of Aragua in Phrygia ${ }^{17}$. In their petition to Philipp the Arab, the peasants of Aragua complain that they were being extremely harassed by the Caesariani, their estates were deserted and destroyed utterly: $\tau \grave{\alpha}$

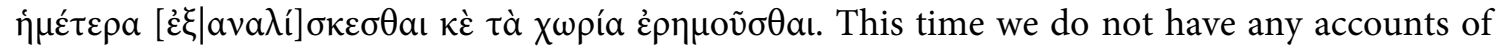
any Caesariani, but other members of familia Caesaris, such as tabellarii. On the other hand, we are of course not sure whether they laid waste the land itself, as is the case in Aragua, because it is also probable that the object in the lacuna may simply be the resources of the villages and that the soldiers exhausted them.

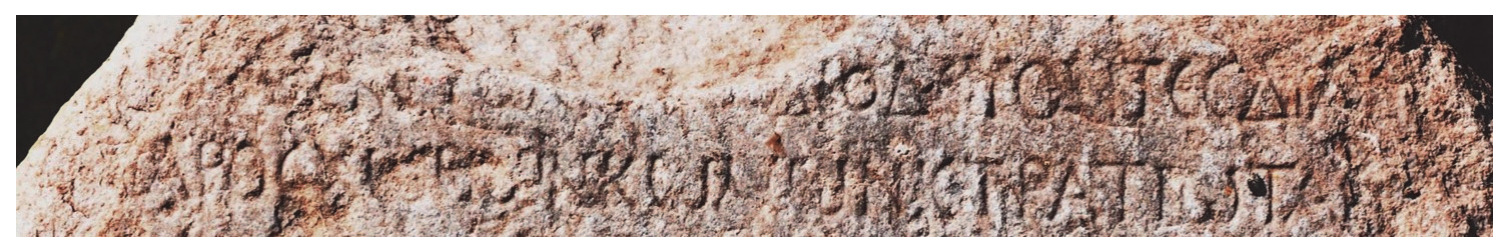

Fig. 1) Details of L. 1-2

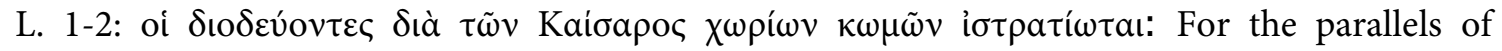

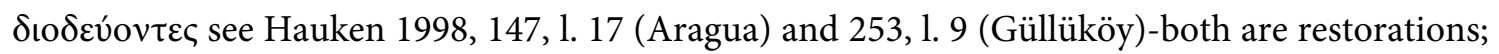

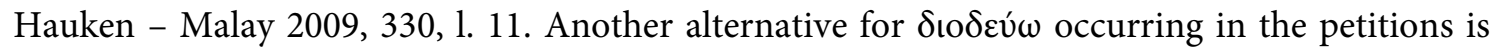
$(\delta ı \alpha) \pi$ o $\varepsilon v ́ \omega$, see Hauken 1998, 189, 11. 12-13 (Kilter); 204, 1. 3 (Euhippe). The common point in these examples employing these terms is that the soldiers were not on their proper routes and they simply left the main highway (leoforos) and attacked the peasants living nearby. Tor Hauken and Hasan Malay has recently argued that the problem emanated from the inclination of the soldiers to avoid accommodation costs, i.e. instead of paying higher amounts for the inns along the public roads, "they went to the villages that had no set procedures to protect themselves against this misuse except through presenting complaints to the Roman authorities ${ }^{18}$." This problem forms one of the basic motives of the inhabitants resorting to the provincial authorities or to the emperor himself with a petition. So, it is almost certain that villagers at the Choria Considiana suffered greatly from the same widespread phenomenon. The nearest main road to the findspot of this inscription is apparently the so-called Pilgrim's Road lying ca. $10-11 \mathrm{~km}$ north $^{19}$ (Fig. 13) and the soldiers in question might have strayed from there to the Choria Considiana ${ }^{20}$ unless they came to the estates from a southern route (i.e. Colonia Germa - Midaion - Dorylaion) ${ }^{21}$. As said, this large imperial estate complex was in close proximity with the Pilgrim's Road as well as the ancient city of Iuliopolis in Galatia about which Pliny the Younger provides an interesting account closely linked to the content of this inscription. In his correspondence with the emperor Trajan, Pliny informs him of the complaints of the Iuliopolitans who endured enormous problems due to the heavy military

\footnotetext{
${ }^{17}$ See Hauken 1998, 140-161, no. 6, 1. 32.

${ }^{18}$ Hauken - Malay 2009, 342-343.

${ }^{19}$ For the Pilgrim's Road, see French 1981.

${ }^{20}$ That the soldiers are off their course is a very common phenomenon in the petitions. Cf. the argument of Hauken and Malay (2009, 342-243) for the reason and motivation of the soldiers for not staying in the guest-houses or lodging-stations along the main road, but instead preferring to exploit the villagers, especially if the estates were notoriously thriving, as it might have been the case for the Choria Considiana.

${ }^{21}$ But cf. the commentaries below for lines 5-6.
} 
traffic passing by and they demanded protection (as was the case for Byzantium) which was refused by the emperor on the grounds that it can set a precedent for many others if Iuliopolis is distinguished ${ }^{22}$. Instead, he entrusts his governor Pliny with ensuring protection for the inhabitants and punishing the culprits severely. The damage suffered by the Iuliopolitans mentioned by Pliny is a strong reminder of the substance of the complaints made by local communities to the provincial or imperial authorities about the abuses perpetrated against them by Roman soldiers or officials. It is clear through our new document that these sorts of abuses continued to be a recurrent problem probably up to the mid- $3^{\text {rd }}$ century A.D. within the territory of Iuliopolis until the unidentified provincial governor of Galatia took repressive measures through this edict to resolve the issue. The fact that a large number of people (soldiers, freedmen, slaves, vicarii, tabularii) is mentioned in the first lines of the inscription and the edict is not addressing a specific group of people most probably indicates that we are not witnessing a particular episode of harassment, but rather a series of abuses committed by various persons on different occasions. This gives us the impression that the governor is here issuing a general order, a precautionary warning against possible future offenses, so that he does not in the future have to intervene. Nonetheless, we cannot say how effective in reality these precautions were, because, as the inhabitants of the village Skaptopara in Thrace, facing similar problems in 230 A.D.

${ }^{22}$ Plin. Epist. 10.77: C. Plinius Traiano Imperatori. Prouidentissime, domine, fecisti, quod praecepisti Calpurnio Macro clarissimo uiro, ut legionarium centurionem Byzantium mitteret. Dispice an etiam Iuliopolitanis simili ratione consulendum putes, quorum ciuitas, cum sit perexigua, onera maxima sustinet tantoque grauiores iniurias quanto est infirmior patitur. Quidquid autem Iuliopolitanis praestiteris, id etiam toti prouinciae proderit. Sunt enim in capite Bithyniae, plurimisque per eam commeantibus transitum praebent $=$ Pliny to the emperor Trajan. It was a very wise move, Sir, to direct the distinguished senator Calpurnius Macer to send a legionary centurion to Byzantium. Would you now consider giving the same assistance to Juliopolis? Being such a small city it feels its burden heavy, and finds its wrongs the harder to bear as it is unable to prevent them. Any relief you grant to Juliopolis would benefit the whole province, for it is a frontier town of Bithynia with a great deal of traffic passing through it; Plin. Epist. 10.78: Traianus Plinio. Ea condicio est ciuitatis Byzantiorum confluente undique in eam commeantium turba, ut secundum consuetudinem praecedentium temporum honoribus eius praesidio centurionis legionarii consulendum habuerimus. $<\mathrm{Si}>$ Iuliopolitanis succurrendum eodem modo putauerimus, onerabimus nos exemplo; plures enim eo quanto infirmiores erunt idem petent. Fiduciam $<$ eam $>$ diligentiae $<$ tuae $>$ habeo, ut credam te omni ratione id acturum, ne sint obnoxii iniuriis. Si qui autem se contra disciplinam meam gesserint, statim coerceantur. aut, si plus admiserint quam ut in re praesenti satis puniantur, si milites erunt, legatis eorum quod deprehenderis notum facies aut, si in urbem versus venturi erunt, mihi scribes = Trajan to Pliny. Byzantium is in an exceptional position, with crowds of travellers pouring into it from all sides. That is why I thought I ought to follow the practice of previous reigns and give its magistrates support in the form of a garrison under a legionary centurion. If I decide to help Juliopolis in the same way I shall burden myself with a precedent, for other cities, especially the weaker ones, will expect similar help. I rely on you, and am confident that you will be active in every way to ensure that the citizens are protected from injustice. If people commit a breach of the peace they must be arrested at once; and, if their offences are too serious for summary punishment, in the case of soldiers you must notify their officers of what is found against them, while you may inform me by letter in the case of persons who are passing through on their way back to Rome (translations excerpted from B. Radice, Pliny the Younger. Letters, Volume I: Books 1-7 [Loeb Classical Library 55], 1969). On this correspondence in detail, see Brélaz 2002, 81-95; Onur 2014, 67. Cf. Sherwin-White 1966, 665-669. Fuhrmann 2012, 45; 222-223. 
underlined ${ }^{23}$, it had become the habit amongst the soldiers at the time to pay no attention to the rules ordered by the highest authorities and the orders were simply disobeyed.

$\chi \omega \operatorname{li}^{\prime} \omega v \kappa \omega \mu \tilde{\omega} v$ : The juxtaposition of the words " $\chi \omega \operatorname{pi}^{\prime} \omega \nu$ and $\kappa \omega \mu \tilde{\omega} v$ " is interesting, which may well be explained in such a way that $\chi \omega$ pia designate the estates/lands themselves, while, on the other hand, $\kappa \tilde{\omega} \mu a \mathrm{l}$ obviously denote the settlements where the village community reside. I have not come across any parallels, but cf. a very late $\left(11^{\text {th }}\right.$ century A.D.) source, Menologii Imperiales,

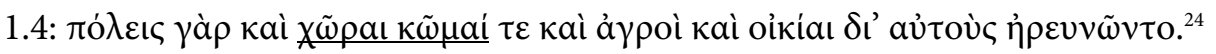

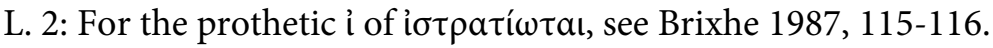

L. 2-3: $\tau \alpha \beta \varepsilon \lambda \lambda$ ápıo. Mason (1974, Index, p. 204) thinks they are synonymous with the tabularii who were serving as accountants primarily in the estates, but as Drew-Bear $(1976,353)$ pointed out, these two terms are not to be confused. Because the beginning of line 3 is not legible, it is not easy to determine if we should restore the missing part with the tabularii or the tabellarii. As imperial couriers who conveyed letters on behalf of public institutions, principally of the emperor/s (tabellarii Augusti), the tabellarii were constantly travelling across the Roman Empire, which makes it almost certain that they were also a part of the problems implied in the inscription. The tabellarii were entitled to obtain free accommodation as well as other provisions, only if they had a valid diploma ${ }^{25}$ and they were permitted to use any means of transport, i.e. animals, wagons along the cursus publicus, only when they had to convey highly significant messages in a short period of time ${ }^{26}$. Now that these messengers are mentioned along with the passing soldiers and other officials, it goes without saying that these messengers were demanding hospitium or perhaps transport from the inhabitants without any authorization to do that. As said, the other possibility for the completion of line would be tabularii (accountant, keeper of archive) ${ }^{27}$, who do not have a taintless record in terms of the abuse of power. An imperial letter from an imperial (?) estate in the territory of Kibyra (modern Karamanl1) from the late $2^{\text {nd }} /$ first half of the $3^{\text {rd }}$ cent. A.D. provides the details on the unjust deeds such as supplementary exactions or even the physical assaults on the peasants of a tabularius named Hedistos and 6 other men (probably leaseholders) ${ }^{28}$.

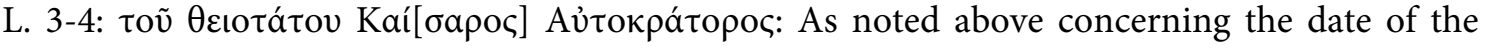
document, the superlative of the "theios" epithet is more commonly attested from the Severan Period onwards. There is no doubt that it refers to a living emperor, not to a deceased one ${ }^{29}$.

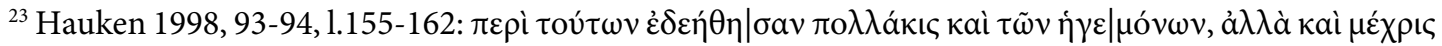

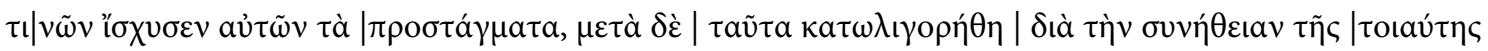
$\varepsilon \dot{\varepsilon} \mathrm{o} \lambda \lambda \dot{\sigma} \sigma \varepsilon \omega \mathrm{s}$ " Even if they have on many occasions entreated the governors about this and their orders have for a while prevailed, the orders were later despised because of this habit of harassing." (Trans. Hauken).

${ }^{24}$ Halkin 1985.

${ }^{25}$ See the epitaph of a tabellarius from Carthago in Africa, CIL VIII, 1027: --- Vitalis Aug(usti) n(ostri) / tabellarius / vivet et convivat / Dum sum Vitalis et vivo ego feci sepulcr $\{\mathrm{h}\} \mathrm{um} /$ adque meos versus dum trans $\{$ s\}eo perlego et ipse / diploma circavi totam regione $(\mathrm{m})$ pedestrem.

${ }^{26}$ Kolb 2000, 295-297.

${ }^{27}$ On tabularii, see Hirschfeld 1963, 58-59; 460-461; Boulvert 1970, 425-426; Weaver 1972, 241.

${ }^{28}$ Souris - Haensch 2009. See the reservation of T. Corsten (op. cit. p. 360, fn. 22) who considers that there is no direct evidence for an imperial estate at Karamanl.

${ }^{29}$ See Rougé 1969, 89 and Merkelbach 2000, 125, who is seemingly unaware of Rougé's study but reaches
} 


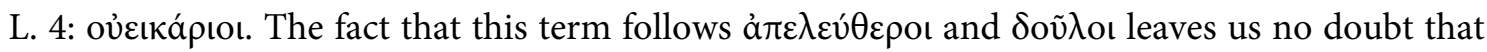
they were not the representative officers in the realm of Roman political organisation who were particularly active after the $3^{\text {rd }}$ century A.D. as vice praefectorum praetorio but they were simply

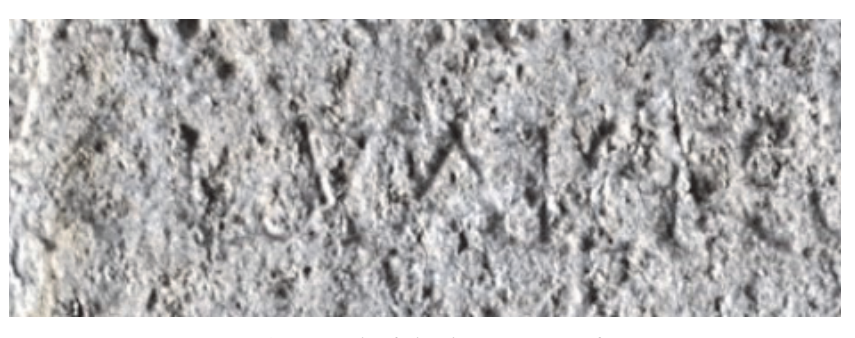

Fig. 2) Detail of the beginning of L. 5 slaves with lower status in the imperial household. As P. R. C. Weaver puts $\mathrm{it}^{30}$, the slave vicarius could be either (a) " $a$ replacement, deputy or auxiliary of a slave official" or (b) "a personal slave of another slave irrespective of function or skill". As far as I know, there is no mention of sort of slaves (either the

freedmen or the others) in the parallel documents except for the Takina dossier ${ }^{31}$ where Caracalla reassures the inhabitants of the estate that his procurator and freedman shall cope with the culprit soldiers who have been harassing them and ravaging their fields. But in our case, it is understood that the freedmen along with the soldiers and other slaves were personally involved in destroying the estate which is rather astonishing.

L. 5: The beginning of this line is rather puzzling and enigmatic. I am very much inclined to restore it as $[\mu \digamma \sigma] \theta \omega \tau \alpha i \tilde{\varphi}$, even though it would be difficult to make sense of the preceding kaí and the succeeding $\tau \varepsilon$ particle syntactically. In this case, the soldiers and other officials are prohibited from demanding anything else than shelter from the mistothai. Cf. the commentaries below in 1 . 6 for what might be the other things that the soldiers are not allowed to ask for. In estate administration, there was a three-phase system, deduced from a series of inscriptions in the province of Africa; the general control was in the hands of a procurator who were responsible for "leasing out the plots of land and collecting the rent and their main duty was to keep the estates productive $e^{32}$ ". The inhabitants of the estate were known as coloni (its Greek equivalent $\pi$ ápooko $\varsigma$ is attested in line 7), to whom the land was rented out by the conductors ( $\mu \sigma \theta \omega \tau \alpha$ i in Greek), i.e. leaseholders who were responsible to the procurators for the overall condition of the estates and were themselves "the recipients of a substantial proportion of the estate's produce" ${ }^{33}$. Nevertheless, one should keep in mind that the terms colonus and conductor can be interchangeably employed ${ }^{34}$ and the misthotai may also refer to the tenants (coloni) who lease and cultivate the land, rather than the large-scale conductores ${ }^{35}$.

the same conclusion; they both stress the fact it is the superlative of the adjective "theios", and the relevant emperor is not a theos yet; but in the Latin speaking world, there is not such a distinction, it is always "divus". In a new dedication erected by the Jewish community in Mysia for the Emperor Hadrian, the ed.pr. C. Tanriver still understands it as "theos" but corrected as "divin" in AE 2013, 1517 by F. Onur. For the epithet, cf. also Hauken 1998, 47-48.

${ }^{30}$ Weaver 1972, 201.

${ }^{31}$ Hauken 1998, 220, Document 1, 1. 4-5.

${ }^{32}$ Dalla Rosa 2016, 309.

${ }^{33}$ Mitchell 1993, 163.

${ }^{34}$ Neeve 1984, 21; Carlsen 1995, 104-109. Cf. also Crawford 1976, 51.

${ }^{35}$ In this sense, this reading does not pose a problem for the assumption of S. Mitchell saying that the 


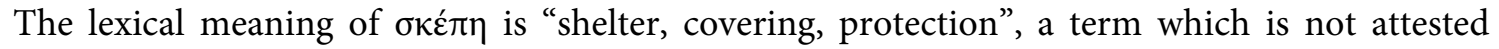
frequently in inscriptions. Epigraphically, it is mostly attested in a funerary context (see for

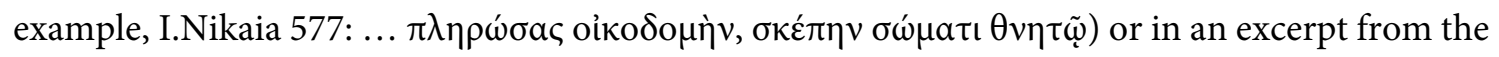
Septuagint (Psalm 90), found repeatedly in the inscriptions of Syria ${ }^{36}$. There are indeed many references to this word in the papyri of the Ptolemaic period, and there is actually a monograph, specifically dedicated to this word ${ }^{37}$, but these papyri concern essentially private patronage relationships, i.e. someone being under the protection of an influential personality. I have not

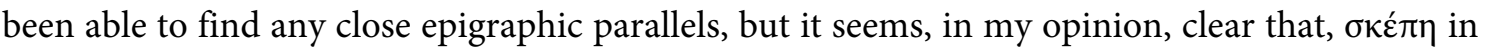

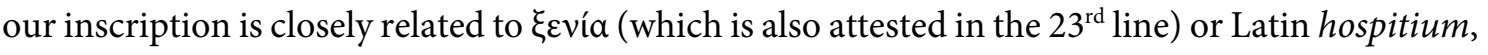
meaning evidently the hospitality provided to soldiers and to officially authorized persons ${ }^{38}$.

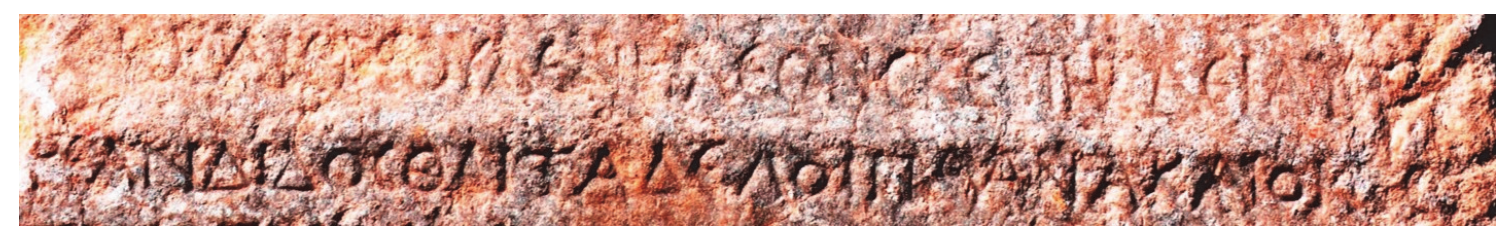

Fig. 3) Details of L. 5-6

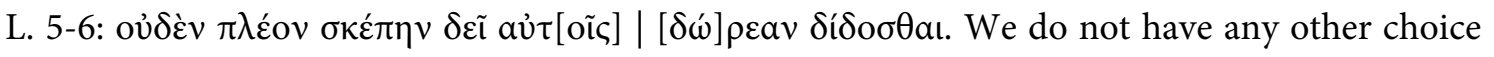
but to complete aủ $\tau$ - as such, given that $\delta \varepsilon \tilde{i}$ requires a dative object. It refers to soldiers and other imperial staff mentioned in the preceding lines. So, the whole sentence demonstrates that the misthotai (either in the sense of leaseholders or the coloni) are required to provide them with shelter without payment, but nothing else $^{39}$.

leasehold system does not seem to have prevailed in the imperial estates of Galatia and the Choria Considiana were compact enough to have been run by an imperial slave oikonomos, without the supervision of a procurator and "the absence of misthotai who can be linked with these imperial estates shows that the peasants would have paid the required portion of their produce directly to the imperial slaves", see Mitchell 1993, 164. Cf. also Güney 2019, 171 who also follows Mitchell's view).

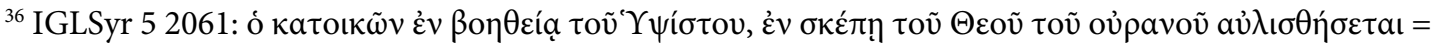
He that dwells in the help of the Highest, shall sojourn under the shelter of the God of heaven).

${ }^{37}$ Piatkowska 1975 (non vidi).

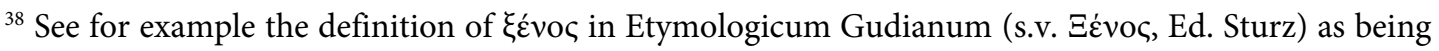

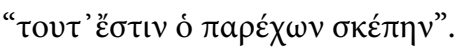

${ }^{39}$ The provision of free lodgings and hospitality to officials in the provinces are attested from many sources starting from the late Republic down to the Late Antiquity. In his correspondence with his friend Atticus, for example (Cic. Ad. Att. V. 10.2; V.16.3), Cicero says that even though he and his legates and his quaestor were technically allowed to claim free shelter, food or any other necessities in accord with the Lex Iulia de repetundis enacted in 59 B.C., he and his staff refrained from exploiting this privilege during his proconsulship in Cilicia in 51 B.C. In the early reign of Tiberius, the legate of Galatia, i.e. Sextus Sotidius Strabo Lubiscidianus, issued a decree, which contains a set of detailed regulations concerning the provision of transport for official use, revealing that not only the legate and the members of his staff, but also the imperial freedmen and the slaves, as well the people on military service were now entitled to claim free billeting (Mitchell 1976, 106-131 = SEG 26, 1392 = I. Sagalassos I, 3). At a relatively late date, in the reign of Gordian III, the inhabitants of the village of Skaptopara in Thrace made allegations against the soldiers, complaining that they left their proper routes, came upon their village, and compelled them to furnish them quartering and most of the other things for their entertainment without offering payment (Hauken 1998, 


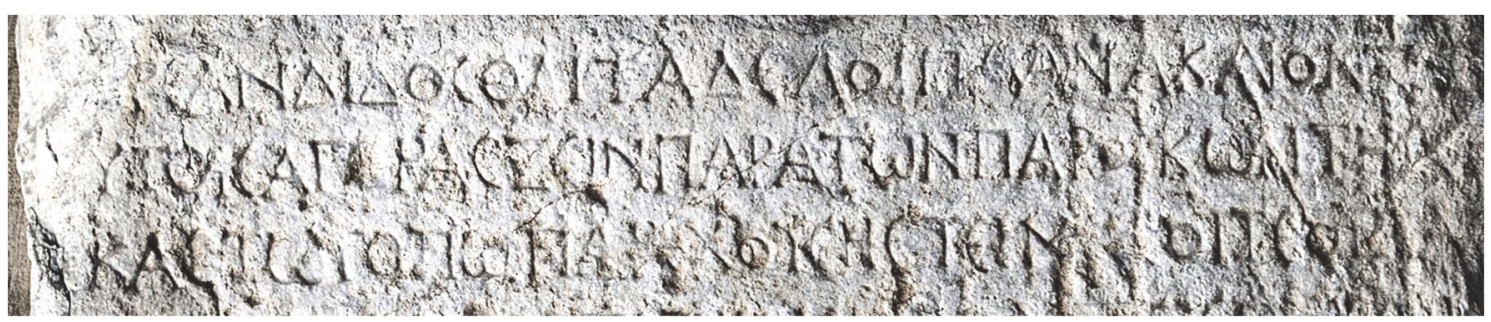

Fig. 4) Details of L.6-8

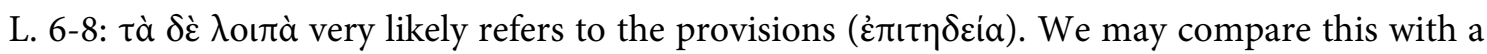

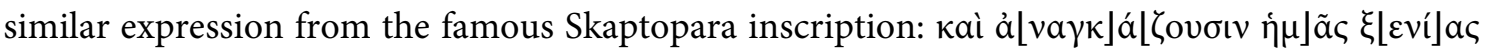

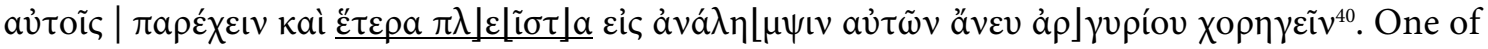
the things that the soldiers requested is beyond doubt $\dot{\varepsilon} \pi \imath \tau \eta \delta \varepsilon$ ia , because in the following lines of the very same inscription, the terms $\xi \varepsilon v i ́ \alpha$ and $\dot{\varepsilon} \pi \imath \eta \delta \varepsilon i \alpha$ are mostly juxtaposed and the peasants persistently complain that they were being compelled to provide the soldiers with quartering and

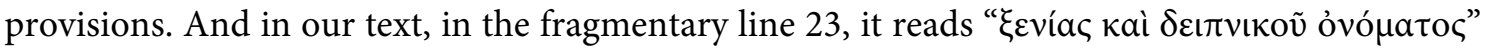
which explains, I believe, the real motivation of the soldiers being in these estates, so to speak, on the pretext of hospitality and meal. The edict of Hadrian actually elaborates it very well, saying that "it shall not be allowed to demand breakfast, dinner, barley or fodder for free, nor should anyone give these when called upon"41. In addition to the provisions, it should be taken into consideration that one other thing we come across in parallel texts is obviously the vehiculatio or in its Greek term "à $\gamma \gamma \alpha \rho \varepsilon i a$ ", i.e. the system of providing horses, mules and conveyances along the roads to the officials. A number of inscriptions record the regulations of transport and address the problems arising from the scheme of requisitions. i.e. who is permitted to use this service and how much they had to pay and what the limitations were, etc. ${ }^{42}$ It is on the other hand not easy to say for sure that $\tau \grave{a} \delta \dot{\varepsilon} \lambda$ oı $\pi \grave{a}$ includes these transport services which the mentioned officials had to pay for, but it is still a possibility.

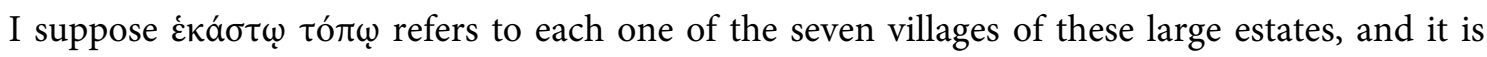
thereby possible to say that each village did determine its own rate of payment for the services rendered.

The expression $\tau \tilde{\eta} \varsigma \pi \alpha \rho \varepsilon \chi o v ́ \sigma \eta \varsigma ~ \tau \varepsilon ı \mu \tilde{\varsigma} \varsigma$ seems to have been attested nowhere to date, neither in

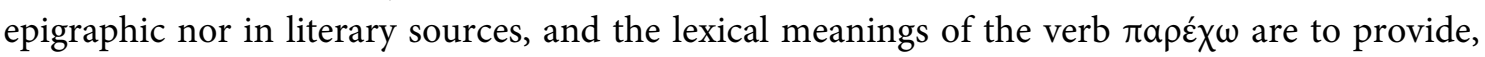

\section{4-139, No. 5).}

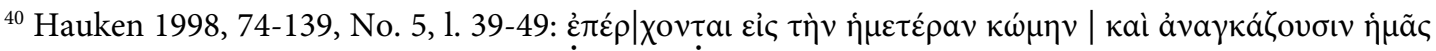

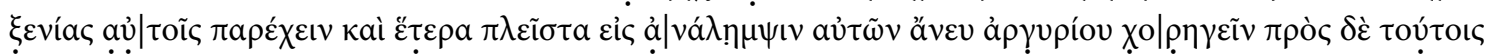

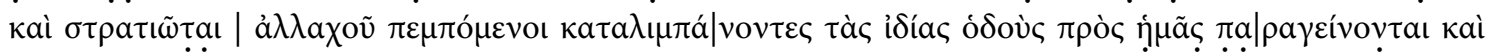

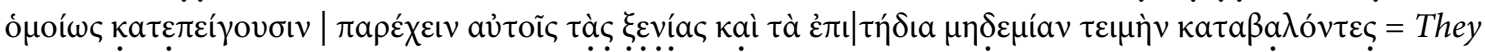
(the soldiers) turn up in our village and compel us to provide them with quartering and most of the other things for their entertainment without offering payment. In addition to these soldiers that are despatched elsewhere leave their proper routes and appear among us and likewise press us hard to furnish them quartering and provisions without paying anything (trans. Hauken).

${ }^{41}$ Hauken - Malay 2009, 329-330, 1. 27-34 = SEG 59, 1365; AE 2009, 1428.

${ }^{42}$ See for example the edict of the Galatian legate, Sextus Sotidius Strabo Libuscidianus, Mitchell 1976, 106-131 = SEG 26, 139 = I.Sagalassos I, 3 or the famous inscription relating to angareia at Sülmenli (Eulandra?) in Phrygia, Frend $1956=$ AE 1957, 167. 
furnish, render, offer, grant, allow etc. The closest amongst them to apply here is to offer, so we may interpret it perhaps, as being "at an offering price, i.e. at the market price". In the edict of

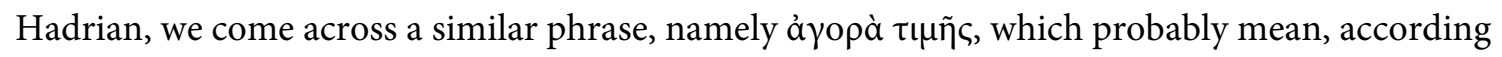
to the editors, «at the market price» to avoid speculation and unjustified price-rising by the villagers ${ }^{43}$. As the editors of that inscription underline, this is very probably a representation of the other side of the conflict; and as Rance has recently put it, "the suppliers of food in the villages or along arterial highways indulged in opportunistic short term price-hiking; and it is not necessarily true that military-civilian interaction was inevitably a one-way exploitative relationship"44.

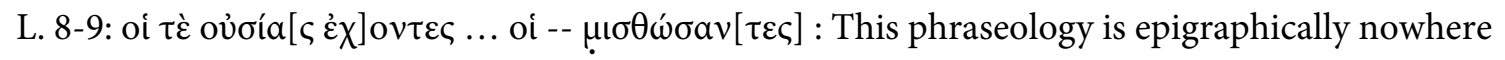
to be found (to my knowledge); but there are so many occurrences in the ancient sources, so I assume the restoration is secure. Keeping it mind that our text is dealing with the imperial estates, not the private ones, it is puzzling to see that the leaseholders are mentioned along with the property owners, i.e. landlords. But the inscription from Henchir Mettich in the Bagradas Valley (in the province of Africa) detailing the tenancy agreement for coloni at Fundus Villae Magnae Variane can be of help in interpreting these lines ${ }^{45}$. According to lines 8-10 of the inscription, the coloni will have to be obliged to provide a certain amount of the crops to the landlords (dominis), leaseholders (conductoribus) and the bailiffs (vilicis). To be able to cope with the difficulties in understanding the circumstances there, D. P. Kehoe has made a proposal saying that despite the fact that the regulation concerns imperial properties, it is assured that the provisions would still apply if the estate was sold to a private individual one day in the future and the domini mentioned in the inscription are future private landlords ${ }^{46}$. So, perhaps it is possible to assert that the governor of Galatia is drawing a general frame for the protection of the tenant-farmers in the future so that owner or any other person that leases it will not have the right to expect anything more than shelter from them ${ }^{47}$.

oi $\mu$ ov $[1-2]=\mu$ óvov? (those who only lease the [property?]).

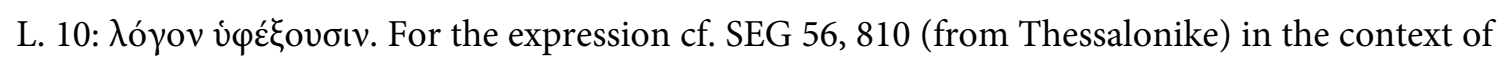
a grave violation where the culprits must face trial in front of the governor for their crimes. Cf. lines 17-19 for a long list of punishments if these gubernatorial orders are not abided with. These punishments are seemingly a simple reflection of disobedience to orders issued by previous legates. As the Skaptopara inscription manifestly displays, it became a habit after some time that the orders of the governors began to be ignored, although they may have prevailed for a while.

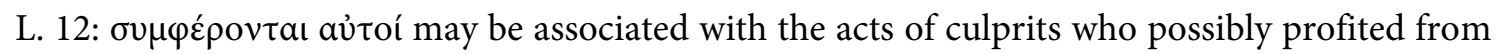
something whose details have fallen victim to the abrasion of the stone in these lines.

\footnotetext{
${ }^{43}$ Hauken - Malay 2009, 342-343.

${ }^{44}$ Rance 2019, 384.

${ }^{45}$ CIL 8, $25902=$ Kehoe 1988, 29-55.

${ }^{46}$ Kehoe 1988, 50.

${ }^{47}$ I am very much indebted to Dr. Alberto Dalla Rosa (Ausonius Institute, Bordeaux) for bringing this inscription to my attention and for his valuable comments.
} 


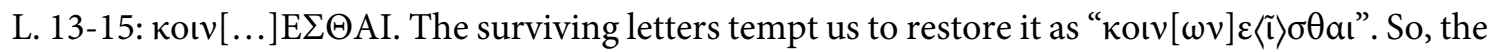
lines 13-15 stipulates that $\tau \grave{\alpha} \mu \varepsilon^{\prime} \rho \alpha$ of the soldiers as well as the freedmen and the slaves are not allowed to be shared with the villages. What is meant by these lines is unclear to me. In case we

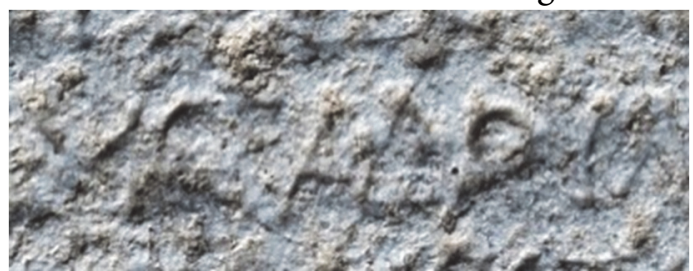

Fig. 5) $\mu \varepsilon ́ \rho \alpha$ in L.14

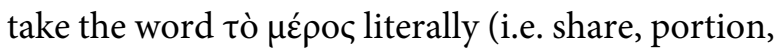
allotment), it gives us the impression that the soldiers and the others were the victims of an improper distribution of something, which sounds rather bizarre, and it is therefore contrary to the nature of the inscription. In the whole petition dossier, the word is attested only twice; one is irrelevant to our topic here ${ }^{48}$; in the other one, it is employed in the sense of business, affair etc, which is yet again inconclusive, in terms of making any sense.

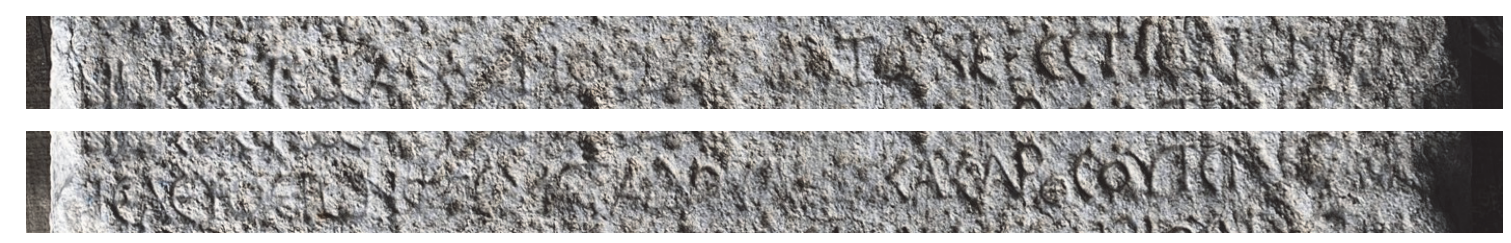

Fig. 6) Details of L. 13-14

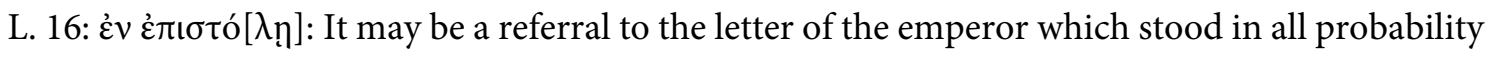

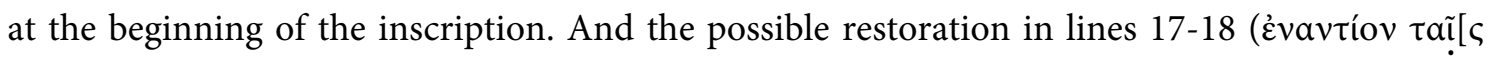

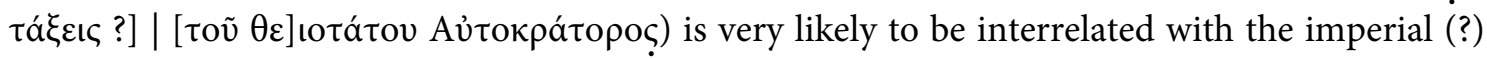
letter here. The regular procedure applied in the petitions was that either the villagers resort to the governor in the province to handle the issue at the provincial level or make an appeal directly to the emperor who then again directed petitioners to the provincial governors with an instruction that they should look into their case. It can be perhaps understood that the inhabitants of Choria Considiana chose the second option. Cf. also 1. 26.

L. 17: $\tau \varepsilon\{\tau \eta\} \theta \dot{\eta} \sigma \varepsilon \tau[\alpha \mathrm{a}]$. The restoration is dubious, but I am unable to provide any better reading. One of the meanings of $\tau i \theta \eta \mu$ is to pay (LSJ, s.v.), so it may possibly be preferred here to distin-

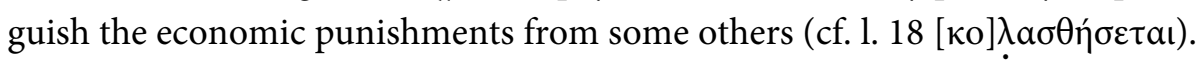

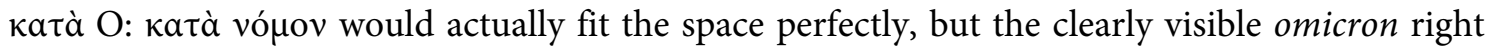
after alpha poses an obstacle to this.

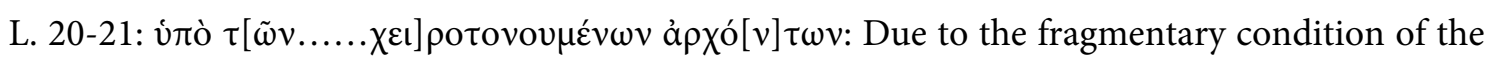
line, it is hard to reconstruct the details of the issue here. But the petition from Güllüköy (Uşak, in the territory of Philadelphia in Lydia) delivered to the proconsul of Asia in 2-3 ${ }^{\text {rd }}$ century A.D. revealing that the peasants were demanding from the governor to instruct the local officials (albeit restored) and the eirenarchs to intervene in the problems on their behalf may help us in this re$\operatorname{gard}^{49}$. In that document, it is not certain if the governor met their demands, but I understand from these lines that the inhabitants of Choria Considiana were successful in their appeal and

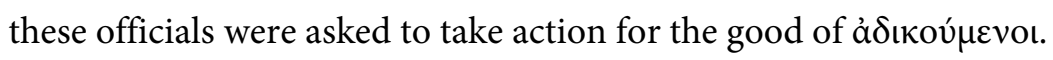

\footnotetext{
${ }^{48}$ See the index in Hauken 1998, p. 350.

${ }^{49}$ Hauken 1998, 251-256, no. 9 (Güllüköy).
} 


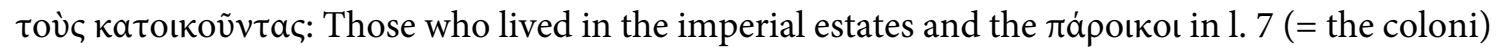
who cultivated the land are distinguished. For a similar situation see Hauken 1998, no. 6 (Aragua inscription), 1.7 and 1.33 .

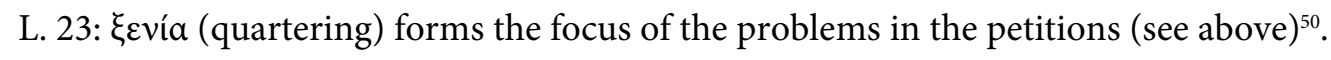

$\delta \varepsilon \imath \tau \nu$ เоṽ: There is no doubt that this is the adjectival form of $\delta \varepsilon \tilde{\varepsilon} \pi v o v$ which is hitherto unattested in any sort of epigraphic, literary or papyrological sources. Similar to $\xi \varepsilon v i ́ a, \delta \varepsilon \tilde{\pi} \pi v v$ was also an incentive for the misbehaviour of the soldiers ${ }^{51}$.

L. 23-25: The readings of these lines pose difficulties in interpreting. I could not come across

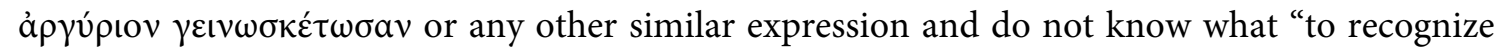
money" means. Taking into the account that the sentence is very likely incomplete here, we should probably consider an accusativus cum infinitivo construction and shouldn't think the àpүúplov is the object of the verb " $\gamma \iota \gamma \nu \omega \sigma \kappa \omega$ "; the translation would be then as such: they [i.e. the soldiers and officials] shall recognize that the money of bootmaker and butcher and the others is.... I do not see any other choice but to suggest that there is yet again possible harassment here, and these lines somehow regulate the trade relations between the groups of tradesmen in the village and the soldiers, as well as the other people involved.

\section{Bibliography}

Akçay 2016

A. Akçay, Epigrafi Araştırmalarında Yeni Bir Belgeleme ve Analiz Metodu Olarak RTI, MJH VI/2, 2016, 1-16.

Boulvert 1970

G. Boulvert, Esclaves et affranchis impériaux sous le Haut-Empire romain. Rôle politique et administratif, Naples 1970.

Brélaz 2002

C. Brélaz, Pline le Jeune interprète des revendications locales: l'epistula 10, 77 et le libellus des Juliopolitains, Appunti Romani di Filologia 4, 2002, 81-95.

Brixhe 1987

C. Brixhe, Essai sur le grec anatolien au début de notre ère, nouvelle édition, Nancy 1987.

Carlsen 1995

J. Carlsen, Vilici and Roman Estate Managers until AD 284, Rome 1995.

Crawford 1976

D. J. Crawford, Imperial Estates, in M. Finley (ed.), Studies in Roman Property, Cambridge 1976, 35-70.

Dalla Rosa 2014

A. Dalla Rosa, Prolegomeni allo studio della proprietà imperiale in Asia Minore: la questione dell'imperatore come acquirente, Scripta Classica et Orientalia 60, 2014, 329-348.

Dalla Rosa 2016

A. Dalla Rosa, From Exploitation to Integration. Imperial Quarries, Estates and Freedmen, and the Integration of Rural Phrygia, Studi Ellenistici 30, 2016, 305-330.

\footnotetext{
${ }^{50}$ For the occurrences, see Hauken 1998, Index p. 350.

${ }^{51}$ For the examples see Hauken 1998, 189, no. 3, 1. 14 (Kilter); Hauken - Malay 2009, 330, 1. 25.
} 
Drew-Bear 1976

French 1981

Frend 1956

Fuhrmann 2012

Güney 2016

Güney 2018

Güney 2019

Güney, forthcoming

Haensch 2006

Haensch 2019

Halkin 1985

Hauken 1998

Hauken - Malay 2009
T. Drew-Bear, Review Article: Latin Terms in Greek: A Discussion, Classical Philology 71, 4, 1976, 349-355.

D. French, Roman Roads and Milestones of Asia Minor. Fasc. I: The Pilgrim's Road, Oxford 1981.

W. H. C. Frend, A Third-Century Inscription Relating to Angareia in Phrygia, JRS 46, 1956, 46-56.

C. Fuhrmann, Policing the Roman Empire: Soldiers, Administration, and Public Order, Oxford 2012.

H. Güney, New inscriptions from the Choria Considiana, Anatolian Studies 66, 2016, 125-139.

H. Güney, Ancient Quarries and Stonemasonry in Northern Choria Considiana, in: D. Matetić Poljak - K. Marasović (eds.), ASMOSIA XI, Interdisciplinary Studies on Ancient Stone, Proceedings of the XI International Conference of ASMOSIA, Split 2015, Split 2018, 621-631.

H. Güney, The sanctuary of Zeus Sarnendenos and the cult of Zeus in northeastern Phrygia, Anatolian Studies 69, 2019, 155174.

H. Güney, The Imperial Estate Choria Considiana and "Zeus of the Seven Villages" in North-West Galatia, in A. Coşkun (ed.), Galatian Victories and Other Studies into the Agency and Identity of the Galatians in the Hellenistic and Early-Roman Periods.

R. Haensch, Von den Augusti liberti zu den Caesariani, in: A. Kolb (ed.), Herrschaftsstrukturen und Herrschaftspraxis Teil: [1.], Konzepte, Prinzipien und Strategien der Administration im römischen Kaiserreich, Berlin 2006, 153-164.

R. Haensch, Übergriffe römischer Soldaten in den östlichen Provinzen des Imperium Romanum, in K. Harter-Uibopuu (ed.), Epigraphische Notizen. Zur Erinnerung an Peter Herrmann, Stuttgart 2019, 249-269.

F. Halkin (ed.), Le ménologe impérial de Baltimore [Subsidia hagiographica 69], Brussels 1985, 157-164 (Retrieved from: http://stephanus-1tlg-1uci-1edu-100135f6s058b.emedia1.bsbmuenchen.de/Iris/Cite ?5059:020:0). Accessed: 15.04.2020.

T. Hauken, Petition and Response. An Epigraphic Study of Petitions to Roman Emperors, 181-249 (Monographs from the Norwegian Institute at Athens 2), Bergen 1998.

T. Hauken - H. Malay, A New Edict of Hadrian from the Province of Asia Setting Regulations for Requisitioned transport, in: R. Haensch (ed.), Selbstdarstellung und Kommunikation: Die Veröffentlichung staatlicher Urkunden auf Stein und Bronze in der Römischen Welt, Munich 2009, 327-348. 
Hauken et al. 2003

Herrmann 1990

Hirschfeld 1963

Kehoe 1988

Kolb 2000

Laffi 1967

Lampe - Tabbernee 2004

Mason 1974

Merkelbach 2000

Mitchell 1974

Mitchell 1976

Mitchell 1993

Neeve 1984

Onur 2014

Piatkowska 1975

Rance 2019

RECAM II

Reger 2020
T. Hauken - C. Tanrıver - K. Akbıyıkoğlu, A new inscription from Phrygia. A Rescript of Septimius Severus and Caracalla to the coloni of the Imperial Estate at Tymion, EA 36, 2003, 33-44.

P. Herrmann, Hilferufe aus römischen Provinzen. Ein Aspekt der Krise des römischen Reiches im 3. Jhdt. n. Chr., Hamburg 1990.

O. Hirschfeld, Die Kaiserlichen Verwaltungsbeamten bis auf Diocletian, Berlin 1963.

D. P. Kehoe, The Economics of Agriculture on Roman Imperial Estates in North Africa (Hypomnemata 89), Göttingen 1988.

A. Kolb, Transport und Nachrichtentransfer im Römischen Reich, Berlin 2000.

U. Laffi, Le iscrizioni relative all'introduzione nel 9 a.C. del nuovo calendario della Provincia d'Asia, Studi Classici e Orientali 16, 1967, 5-98.

P. Lampe - W. Tabbernee, Das Reskript von Septimius Severus und Caracalla an die Kolonen der Kaiserlichen Domäne von Tymion und Simoe, EA 37, 2004, 169-178.

H. J. Mason, Greek terms for Roman institutions: A lexicon and analysis, Toronto 1974.

R. Merkalbach, @EIOTATO $\Sigma$ AYTOKPAT $\Omega$ P, EA 32, 2000, 125.

S. Mitchell, The Plancii in Asia Minor, JHS 64, 1974, 27-39.

S. Mitchell, Requisitioned Transport in the Roman Empire: A New Inscription from Pisidia, JRS 66, 1976, 106-131.

S. Mitchell, Anatolia: Land, Men, and Gods in Asia Minor, Volume I: The Celts in Anatolia and the Impact of Roman Rule, Oxford 1993

P. W. Neeve, Colonus: Private Farm-Tenancy in Roman Italy During the Republic and the Early Principate, Amsterdam 1984.

F. Onur, Epigraphic Research around Juliopolis I: A Historical and Geographical Overview, Gephyra 11, 2014, 65-83.

M. Piatkowska, La $\Sigma \mathrm{KE} \Pi \mathrm{H}$ dans l'Égypte ptolémaïque (Archiwum Filologiczne 32), Wroclaw 1975.

P. Rance, The Farmer and the Soldier Should Be Friends: Justinian's Legislation on the Provisioning of Soldiers (Novel 130), Journal of Late Antiquity 12.2, 2019, 380-421.

S. Mitchell, Regional Epigraphic Catalogues of Asia Minor II: The Inscriptions of North Galatia. The Ankara District (British Institute of Archaeology at Ankara Monograph no. 4), Oxford 1982.

G. Reger, A Letter of Septimius Severus to the Lykian League on the Misbehavior of Soldiers. A New Inscription from Choma (Hacımusalar Höyük), Chiron 50, 2020, 253-285. 
Rougé 1969

Scheidel 1991

Sherwin-White 1966

Souris - Haensch 2009

Speidel 2009

Speidel 2015

Tabbernee - Lampe 2008

Tanriver 2013

TIB 4

Weaver 1972

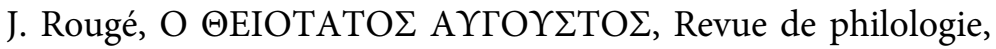
de littérature et d'histoire anciennes 43, 1969, 83-92.

W. Scheidel, Dokument und Kontext: Aspekte der historischen Interpretation epigraphischer Quellen am Beispiel der „Krise des dritten Jahrhunderts“, Rivista Storica dell'Antichità 21, 1991, 145-164.

A. N. Sherwin-White, The Letters of Pliny, A Historical and Social Commentary, Oxford 1966.

G. Souris - R. Haensch, RECAM III, 112 (SEG 48, 1583): Abuse of Power by members of the Roman administration and the Imperial Reaction, in: R. Haensch (ed.) Selbstdarstellung und Kommunikation. Die Veröffentlichung staatlicher Urkunden auf Stein und Bronze in der Römischen Welt, Munich 2009, 349-365. M. A. Speidel, Les longues marches des armées romaines. Reflets épigraphiques de la circulation des militaires dans la province d'Asie au IIIe siècle apr. J.-C.. Cahiers du Centre Gustave Glotz 20, 2009, 199-210.

M. A. Speidel, Kaiserliche Privilegien, Urkunden und die „Militäranarchie“ des Zeitalters der „Soldatenkaiser“. Einige Beobachtungen, in: U. Babusiaux - A. Kolb (eds.), Das Recht der „Soldatenkaiser“. Rechtliche Stabilität in Zeiten politischen Umbruchs?, Berlin-Munich-Boston 2015, 46-64.

W. Tabbernee - P. Lampe, Pepouza and Tymion. The Discovery and Archaeological Exploration of a Lost Ancient City and an Imperial Estate, Berlin-New York 2008.

C. Tanrıver, Mysia’dan Yeni Epigrafik Buluntular, İzmir 2013.

K. Belke (mit Beiträgen von M. Restle), Tabula Imperii Byzantini 4: Galatien und Lykaonien, Vienna 1984.

P. R. C. Weaver, Familia Caesaris: A Social Study of the Emperor's Freedmen and Slaves, Cambridge 1972. 


\section{Galatia-Phrygia Sınırında Roma Askerleri ve İmparator Çiftlikleri: Eskișehir Müzesi'nden Yeni Bir Yazıt \\ Özet}

Bu makalede, Pessinus, Midaion, Nakoleia ve elbette Dorylaion gibi yerleşim yerlerinden getirilen pek çok esere ev sahipliği yapan Eskişehir Arkeoloji Müzesi'nden yeni bir yazıt bilim dünyasına tanıtılmaktadır. Mermer bir levha üzerine kazınan yazıt müze yetkililerinin verdiği bilgiye göre Eskişehir il merkezinin yak. $100 \mathrm{~km}$ kuzeydoğusunda yer alan Mihalıççık ilçesinde bulunmuştur. Daha önceden yayımlanan yazıtlar, bu alanın önemli bir bölümünün Antik Dönem'de 7 köyden oluşarak en geç Hadrianus döneminde imparatorun patrimonium'una dahil edilen Choria Con-

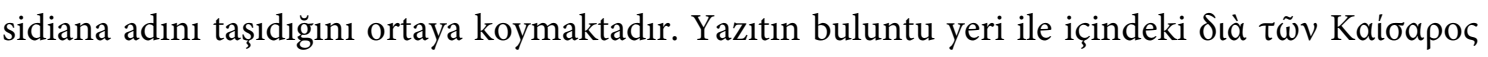

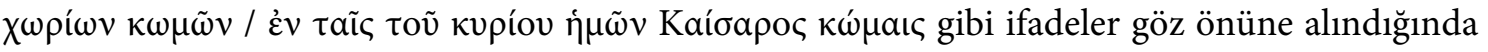
yazıtta adı geçen imparator arazilerinin Choria Considiana ile özdeş olduğu rahatlıkla söylenebilmektedir. Yazıt, çok büyük olasılıkla Galatia eyalet valisi tarafından kaleme alınmış olan bir edictum niteliğindedir ve Choria Considiana sakinlerinin askerlerin ve tabellarii gibi diğer görevlilerin yasal olmayan uygunsuz tutumları ve hareketleri dolayısıyla sıkıntılı zamanlar geçirdiğini ortaya koymaktadır. Yazıtta belirtilen düzenlemelere göre bundan böyle askerler ve görevliler artık

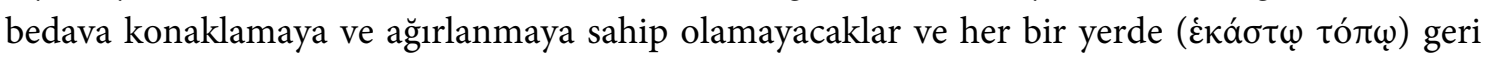

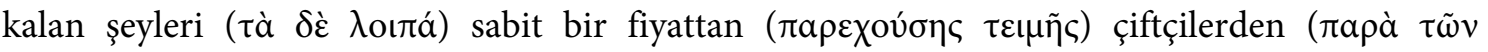

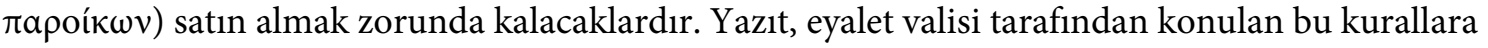
uymayanların detayları taşın ilgili bölümünün tam okunamaması nedeniyle bilinmeyen cezalara maruz kalacağını göstermektedir. Bu düzenlemelerin uzun vadede işe yarayıp yaramadığı belli değildir, çünkü Skaptopara yazıtının da gösterdiği gibi bir süre yürürlükte kalmasına rağmen bu emirlere riayet edilmediği ve aynı sorunların tekrar tekrar yaşandığı bilinmektedir. İmparatorun ya da eyalet valisinin ismi yazıtta geçmediğinden tarihleme yapabilmek için elimizde bir ipucu yoktur; ama köylülerin şikayetlerini bildirdiği dilekçeler ve buna Roma yetkililerin verdiği cevapları içeren benzer yazıtların çoğunlukla MS 2. yüzyılın sonu ile 3. yüzyılın ilk yarısına yoğunlaşmış olması, yeni yazıtı da aşağı yukarı bu dönemlere tarihlemek için uygun görünmektedir. Bu tarih aralı̆̆ı yazıtın harf karakteri ile de uyum içindedir. Yazıtın Türkçe çevirisi ise şöyledir:

Imparatorun çiftliklerinden geçen askerler, imparatorun ulakları, tanrısal imparatorun azatlları, köleler, vicarius'lar ... (köylerin kaynaklarını?) tüketmesin! Misthotai'lar için (= müstecirler?) bedava konaklamadan başka birşey sağlamak zorunlu değildir. Geri kalan şeyleri onların her bir yerde pazar fiyatı üzerinden çiftçilerden almaları zorunludur. Bu kurallara karşı gelen hem mülk sahipleri (?) hem de müstecirler benzer şekilde hesap vereceklerdir. --- Engellenmiştir ve tehlikelidir ---- Bunlar arasında hiçkimseye (?) ne azatlların ne imparatorun kölelerinin ne de vicarii'nin payının (??) köylere dağıtılması (?) için müsaade olmadiğını bildiklerinden ---- Eğer birisi mektupta yazılanlara karşı bir harekette bulunursa --- sadece --- aynı zamanda cezalandırılacak --- tanrısal imparatorumuzun (emirlerine ?) karşı olan ---- seçilmiş arkhonlar tarafindan imparator efendimizin köylerinde zarar ziyana uğrayan sakinleri ---- ayakkabıcının ve kasabın ve diğerlerinin parasının ---- bilsinler ----- ne arkhon'a ne de --- herhangi bir şekilde ---

Anahtar Sözcükler: Choria Considiana, Eskişehir Müzesi, Iuliopolis, Roma ordusu, familia Caesaris, imparator arazileri, misthotai, konaklama, şikâyet ve cevap. 


\title{
Roman Soldiers and Imperial Properties in the Galatian-Phrygian Borderland: a new inscription from the Eskișehir Museum
}

\begin{abstract}
\end{abstract}
In this paper, the author introduces a new inscription from the Eskişehir Archaeological Museum which houses a numerous collection of inscribed material from the main civic centres such as Pessinous, Midaion, Nakoleia and chiefly of course from Dorylaion. This inscription, carved on a marble slab was discovered in the county of Mihalıççı, ca. $100 \mathrm{~km}$ north-east of Eskişehir (ancient Dorylaion). According to the some previously published inscriptions, a large part of this county was called Choria Considiana in antiquity, which comprised seven villages and was incorporated into the patrimonium Caesaris as early as the reign of Hadrian. Given the find-spot and

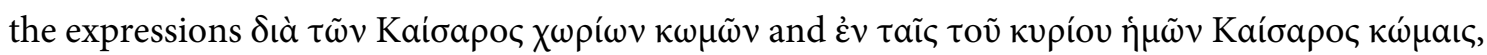
it can be securely said that the imperial estate recorded in this new inscription is identical with that named Choria Considiana. The inscription in all likelihood concerns an edict issued by the imperial legate of the province of Galatia and it shows that the inhabitants of Choria Considiana experienced tough times due to the inappropriate and illegal behaviour of military men and some imperial staff such as freedmen of the emperor and tabellarii. This edict stipulates that the soldiers and other officials shall not be provided with free lodgings and hospitality and they are required to buy the remaining things ( $\tau \grave{\alpha} \delta \grave{\varepsilon} \lambda o \imath \pi \alpha ́$ ) at an offering price i.e. at the market price ( $\pi \alpha \rho \varepsilon \chi o u ́ \sigma \eta \varsigma$

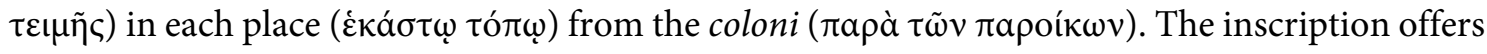
a list of punishments whose details are not known due to the fragmentary condition of those parts of the stone, if these gubernatorial orders are not adhered to. We are not sure whether these became effective in the long term based on the fact that the Skaptopara inscription manifestly records it had become a habit after some time that the orders of the governors began to be ignored, although they may have been followed for a while. There is unfortunately no hint as to the date of the inscription, because the name of the emperor or the governor is not recorded. Considering the parallel texts which also contain the complaints of the villages to the emperors and the responses they receive and which are mostly found within specific time span, ranging from the end of the $2^{\text {nd }}$ century to the first half of the $3^{\text {rd }}$ century A.D., one can also propose a similar date for this new inscription, which is also supported by the lettering forms employed.

Keywords: Choria Considiana, Eskişehir Museum, Iuliopolis, Roman army, familia Caesaris, imperial estates, misthotai, quartering, petition and response. 


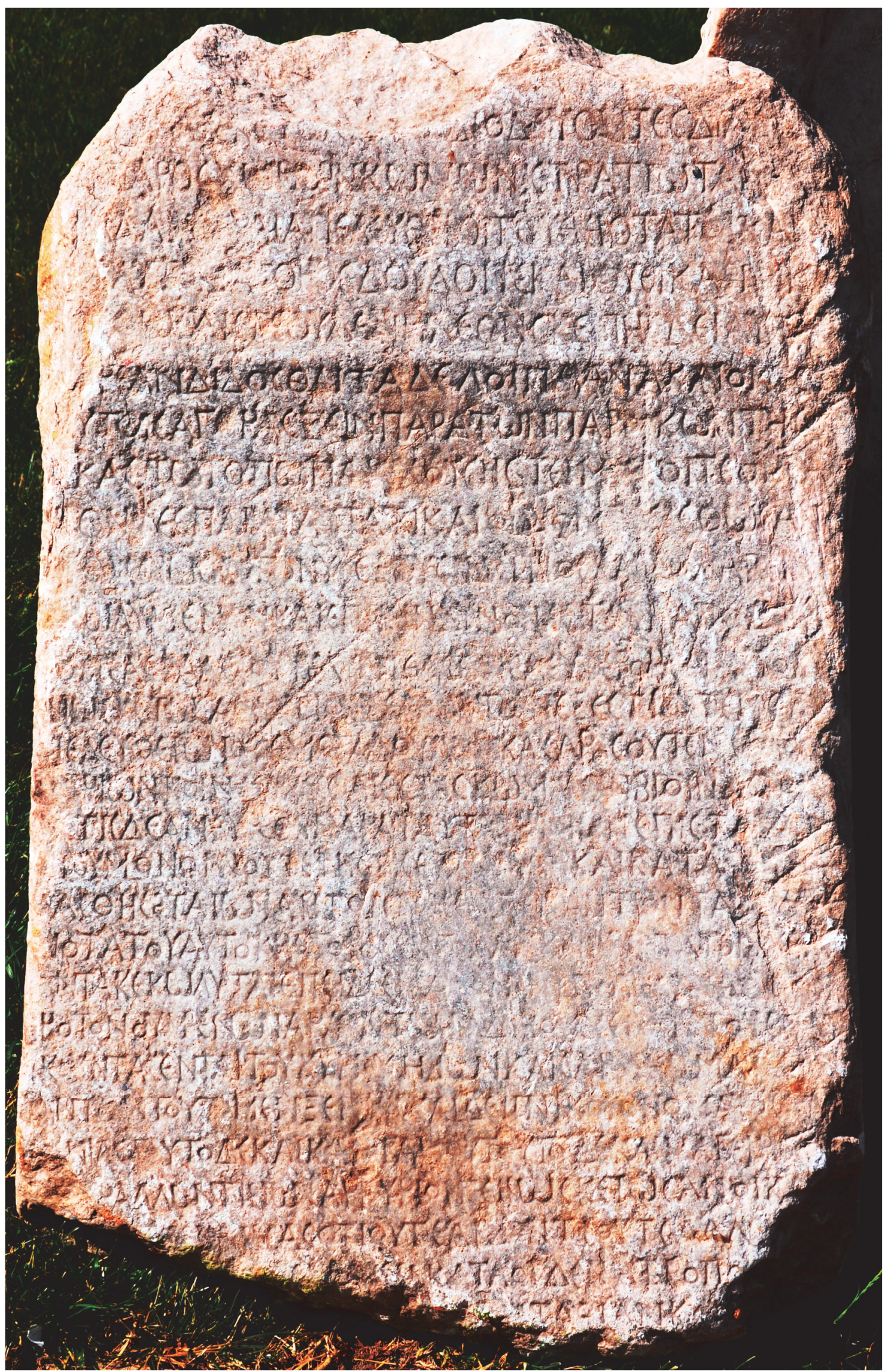

Fig. 7) The inscription (from the archive of Prof. Dr. N. Eda Akyürek Şahin) 


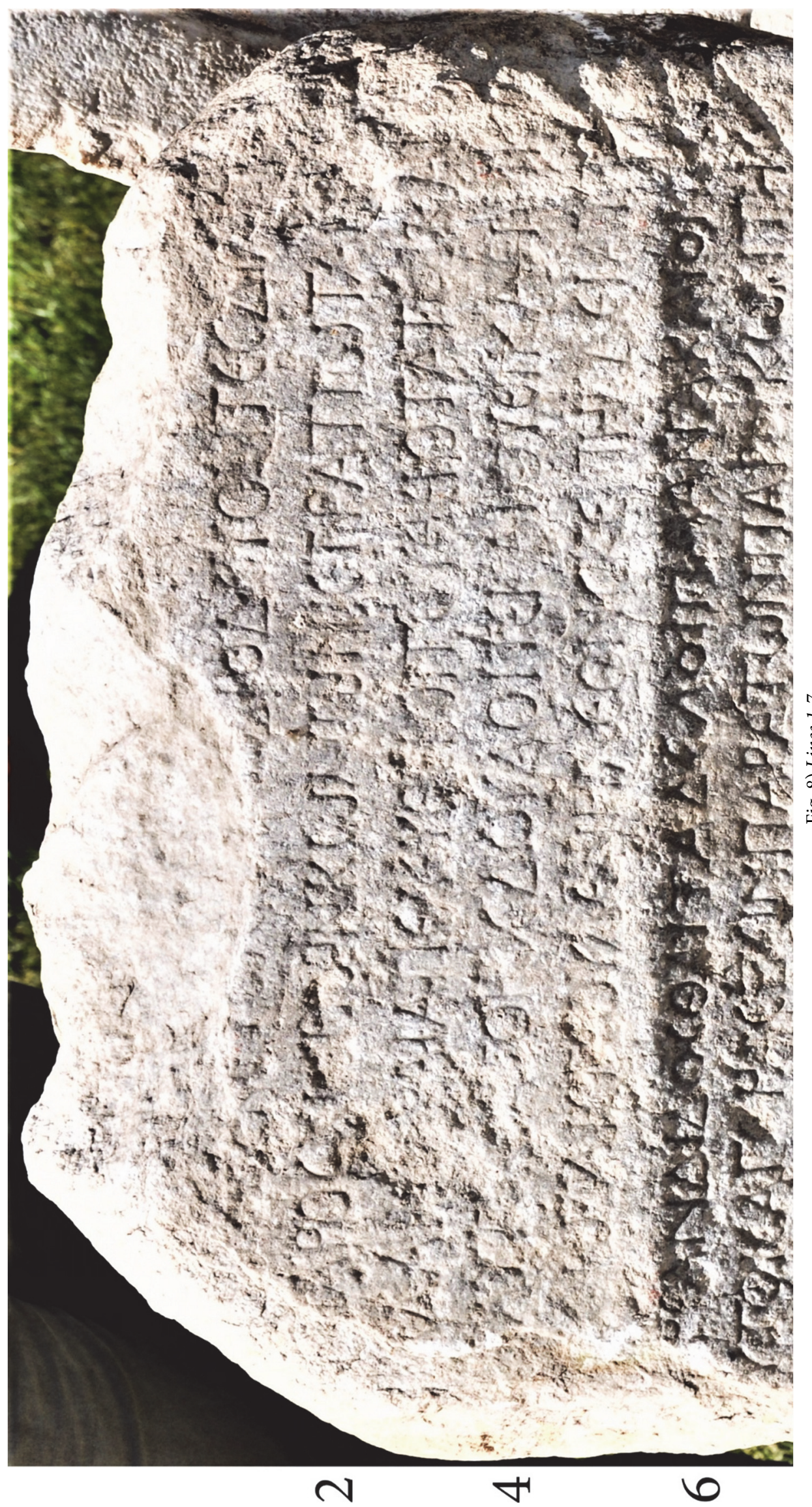




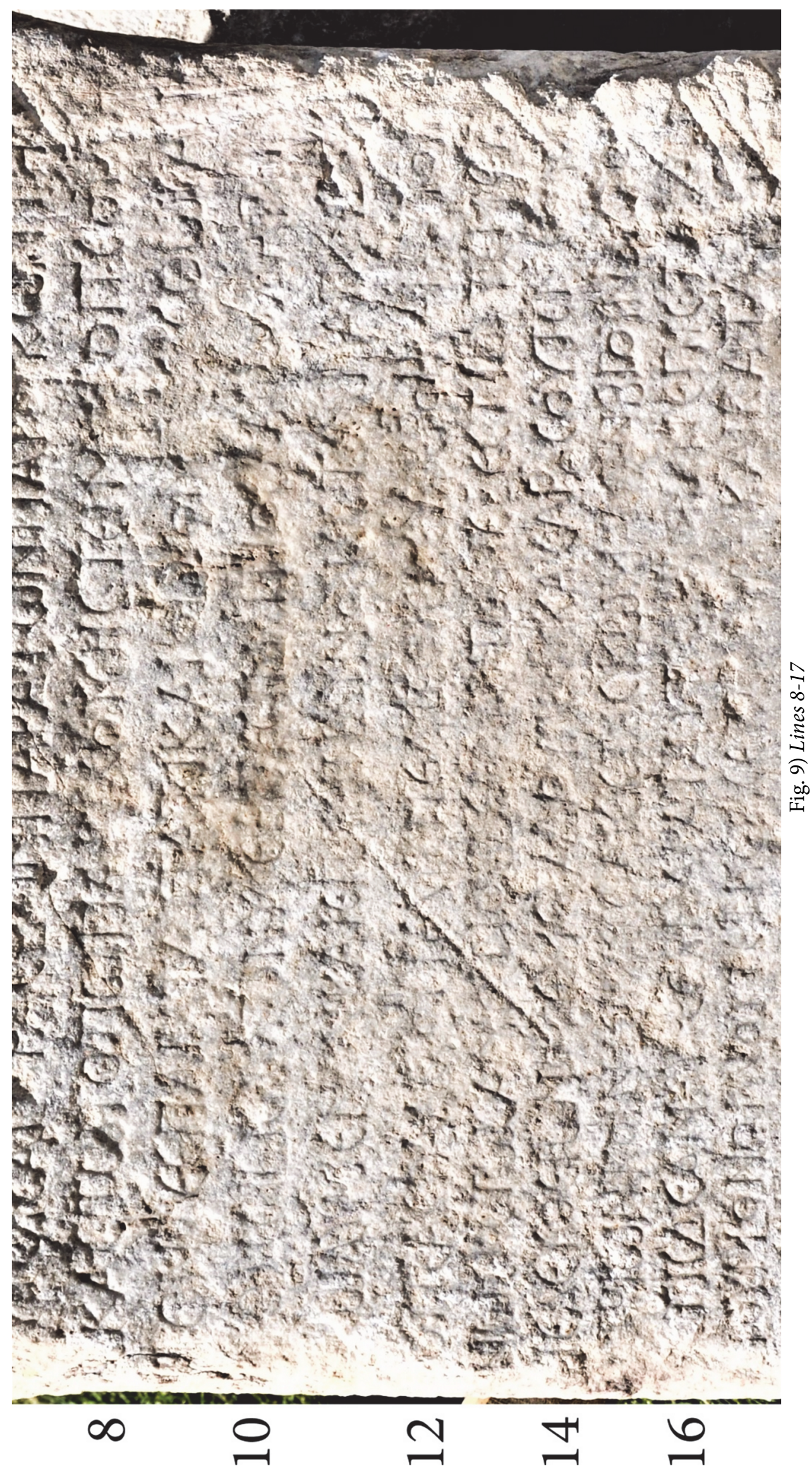




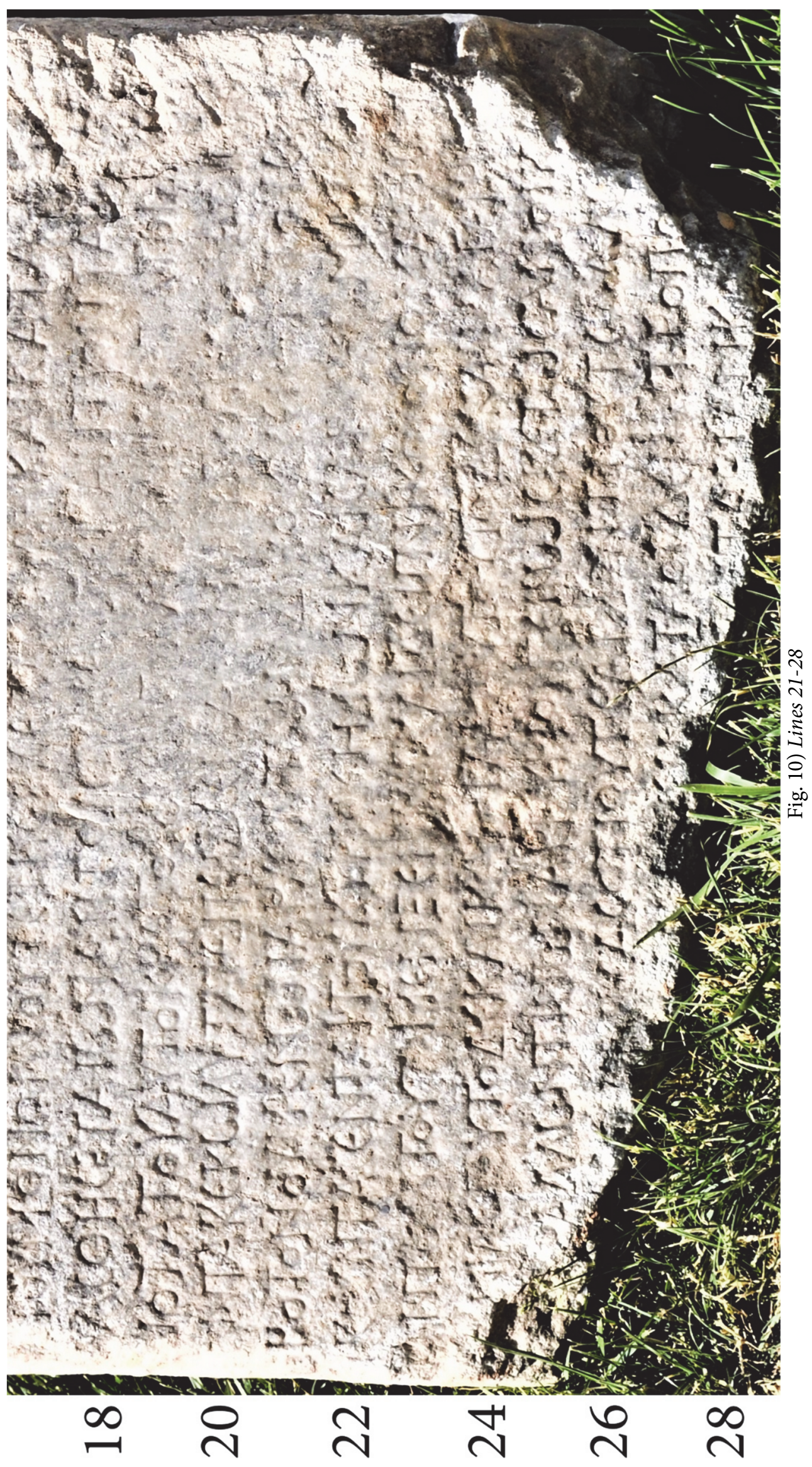




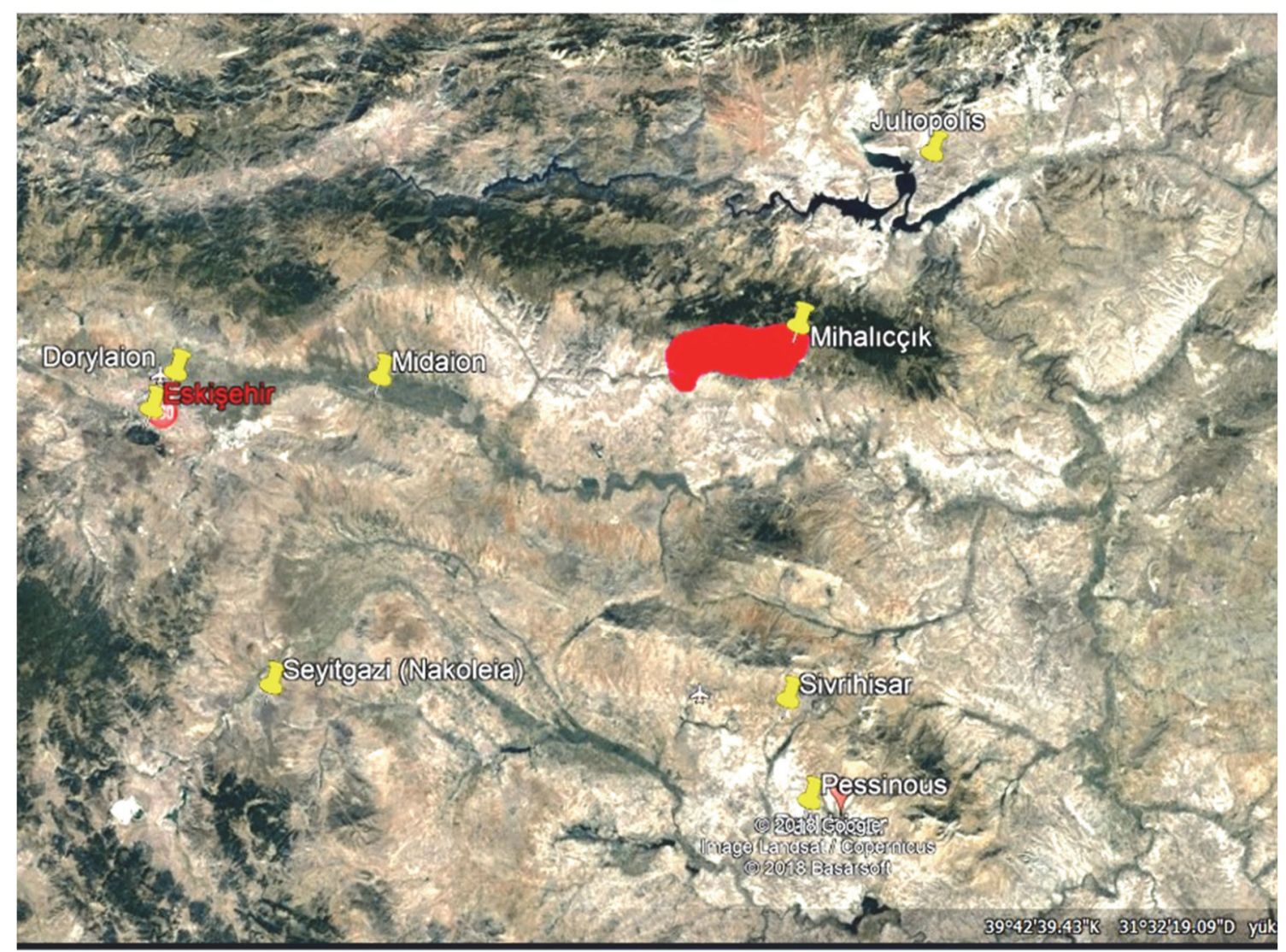

Fig. 11) The findspot of the inscription (painted in red) and its environs (Google Maps)

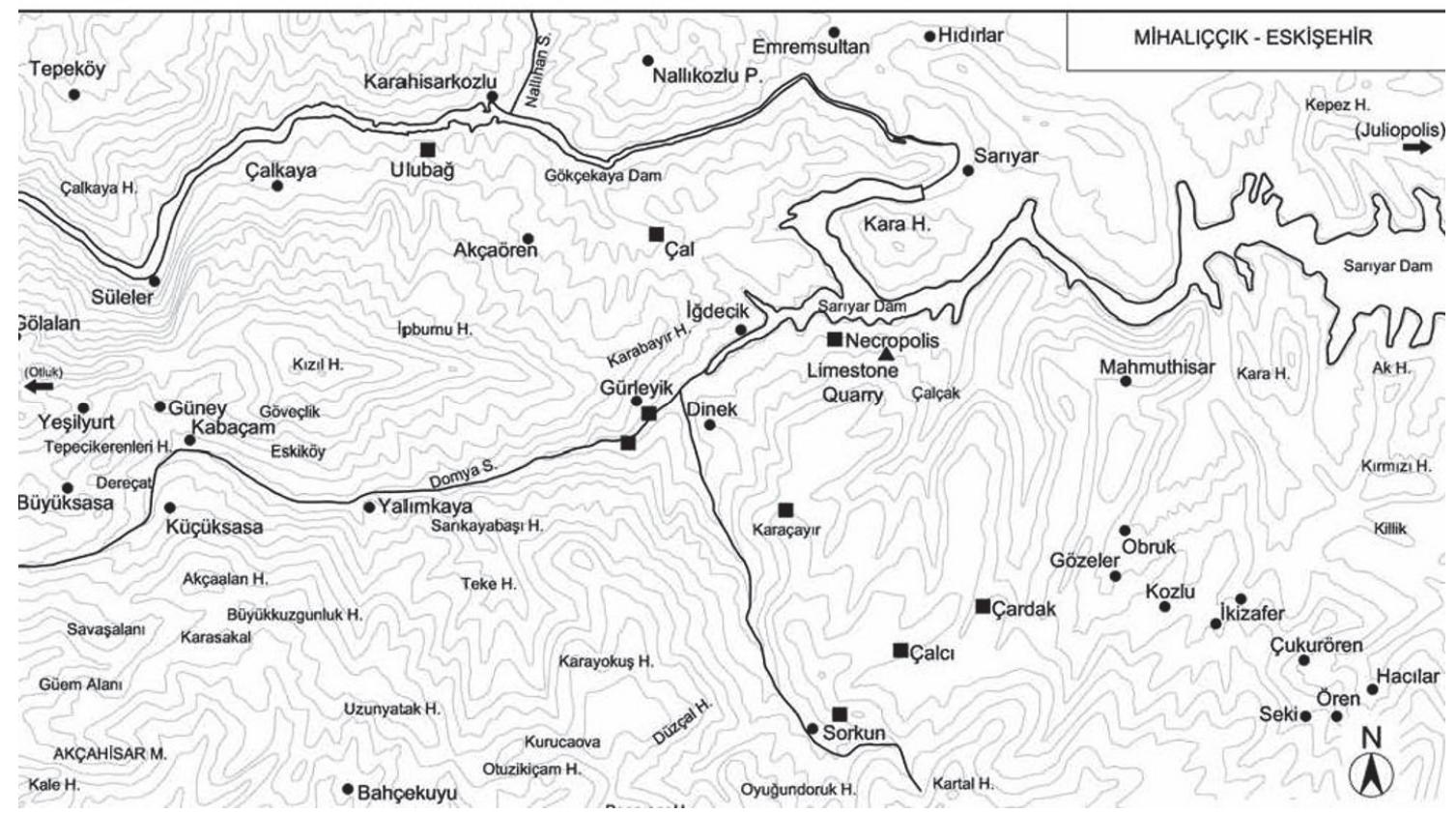

Fig. 12) Estimated territory of Choria Considiana (Güney 2016, 125-139). 


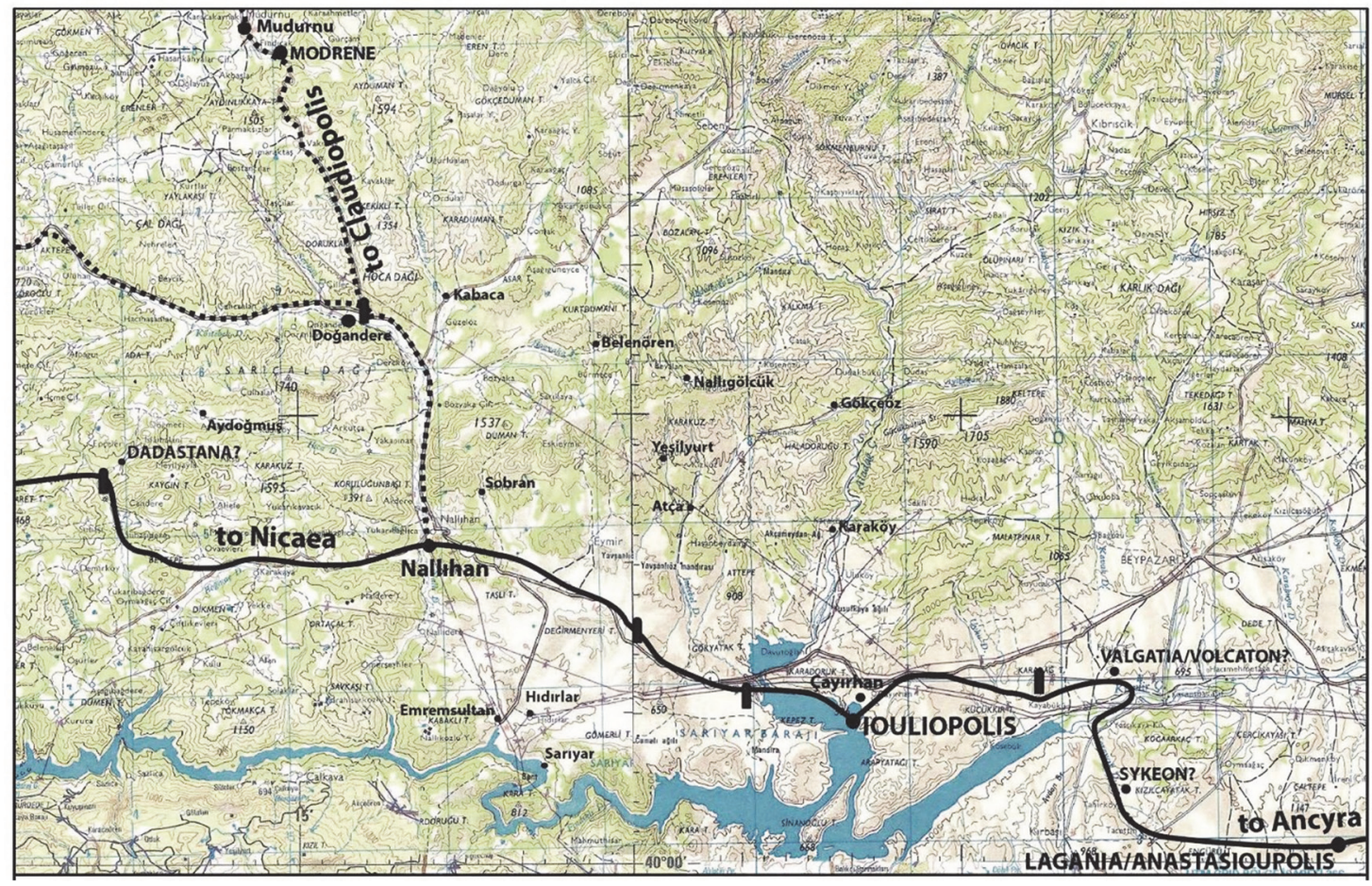

Fig. 13) The Pilgrim's road (after Onur 2014)

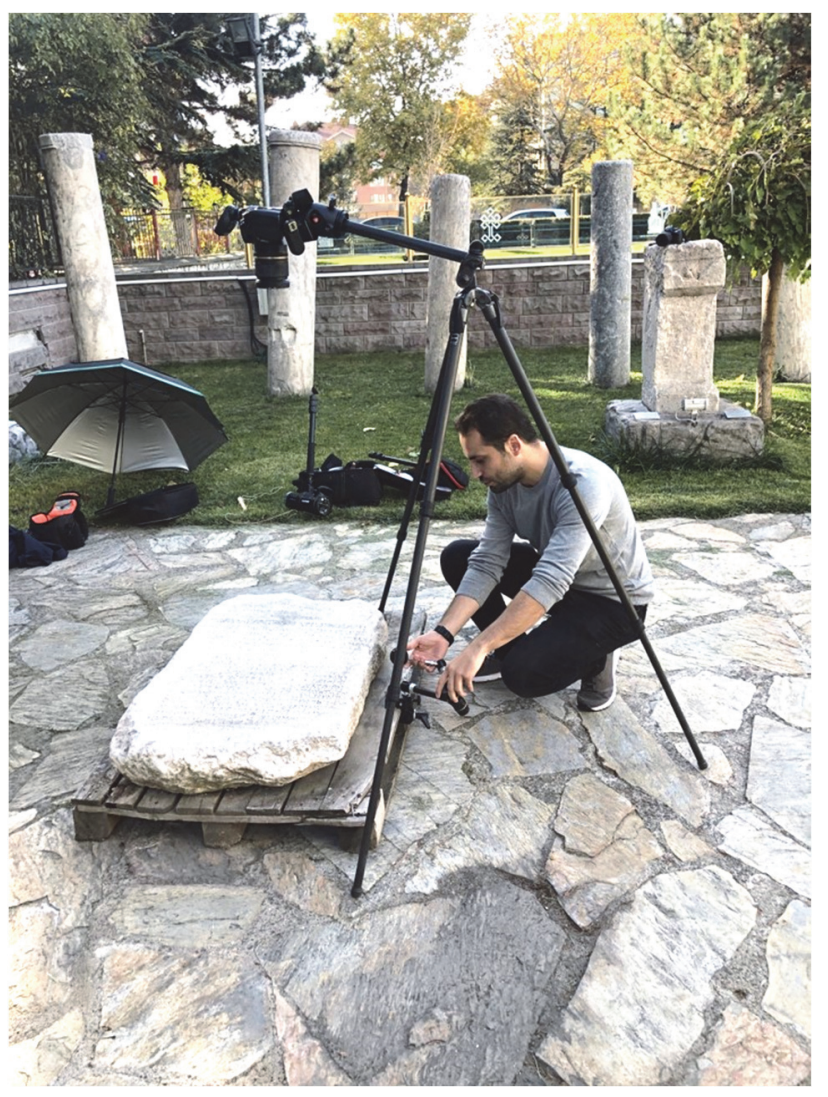

Fig. 14) The application of RTI by A. Akçay (November 2019) 